\title{
Review \\ Electrospun Ceramic Nanofibers for Photocatalysis
}

\author{
Yan Xing ${ }^{1,2}$, Jing Cheng ${ }^{2}$, Heping $\mathrm{Li}^{2}$, Dandan Lin ${ }^{2}$, Yuting Wang ${ }^{2}$, Hui Wu ${ }^{2}$ and Wei Pan ${ }^{2, *(1)}$ \\ 1 School of Science, Nanjing University of Posts \& Telecommunications (NUPT), Nanjing 210023, China; \\ xingyan618@njupt.edu.cn \\ 2 State Key Lab of New Ceramic and Fine Processing, School of Materials Science and Engineering, Tsinghua \\ University, Beijing 100084, China; chengj88@mail.sysu.edu.cn (J.C.); liheping@hust.edu.cn (H.L.); \\ lindd04@163.com (D.L.); yutingwang@ustb.edu.cn (Y.W.); huiwu@tsinghua.edu.cn (H.W.) \\ * Correspondence: panw@mail.tsinghua.edu.cn; Tel.: +86-010-6277-2859
}

Citation: Xing, Y.; Cheng, J.; Li, H.; Lin, D.; Wang, Y.; Wu, H.; Pan, W. Electrospun Ceramic Nanofibers for Photocatalysis. Nanomaterials 2021, 11, 3221. https://doi.org/10.3390/ nano11123221

Academic Editor: Andreu Cabot

Received: 4 November 2021

Accepted: 24 November 2021

Published: 27 November 2021

Publisher's Note: MDPI stays neutral with regard to jurisdictional claims in published maps and institutional affiliations.

Copyright: () 2021 by the authors. Licensee MDPI, Basel, Switzerland. This article is an open access article distributed under the terms and conditions of the Creative Commons Attribution (CC BY) license (https:// creativecommons.org/licenses/by/ $4.0 /)$.

\begin{abstract}
Ceramic fiber photocatalysts fabricated by electrospinning hold great potential in alleviating global environmental and energy issues. However, many challenges remain in improving their photocatalytic efficiencies, such as the limited carrier lifetime and solar energy utilization. To overcome these predicaments, various smart strategies have been invented and realized in ceramic fiber photocatalysts. This review firstly attempts to summarize the fundamental principles and bottlenecks of photocatalytic processes. Subsequently, the approaches of doping, surface plasmon resonance, and up-conversion fluorescent to enlarge the light absorption range realized by precursor composition design, electrospinning parameter control, and proper post heat-treatment process are systematically introduced. Furthermore, methods and achievements of prolonging the lifetime of photogenerated carriers in electrospun ceramic fiber photocatalysts by means of introducing heterostructure and defective composition are reviewed in this article. This review ends with a summary and some perspectives on the future directions of ceramic fiber photocatalysts.
\end{abstract}

Keywords: electrospinning; ceramic fibers; photocatalysts

\section{Introduction}

Electrospinning is a fascinating technique that allows the fabrication of continuous fibers with diameters down to a few nanometers [1-3]. Since Cooley issued the first electrospinning patent in 1902 [4], this technology did not receive much attention until the research boom of nanomaterials in the 1990s. Now, electrospinning is widely recognized as a simple, versatile, and scalable method for preparing both polymer and ceramic nanofibers [5-9]. Typically, a high-voltage source, solution reservoir, spinning nozzle, and grounded collector are the main components of electrospinning equipment [2]. By adjusting relevant parameters, such as the distribution of the electric field, viscosity and surface tension of precursor solution, the size and shape of the nozzle, and the collector structure, the microstructure and morphology of the fibers can be finely controlled [10-13]. Because the fiber products usually exhibit high porosity, good flexibility, large specific surface area, and a uniform diameter, they shows wide application prospects in the fields of filtering [14], biological tissue engineering [15], electronic devices [16], and photocatalysis [17].

Energy shortages and environmental pollution are urgent issues facing humanity, despite the fact that the solar energy reaching the Earth far exceeds the global energy consumption $[18,19]$. Semiconductor photocatalysis can utilize renewable solar energy to initiate chemical redox processes such as pollutant degradation and hydrogen generation, solving the environmental and energy issues in a green, low-cost, and sustainable way [20-22]. Since Fujishima and Honda discovered photo-assisted electrochemical water oxidation on $\mathrm{TiO}_{2}$ electrode in 1972 [23], photocatalysts based on semiconductor materials have been studied extensively [24-26]. Numerous research groups have evolved to synthesize oxide semiconductor catalysts with different scales, morphology, and structure, 
and characterized their photocatalytic properties [27-29]. Among them, 1D ceramic fibers prepared by electrospinning of precursor nanofibers followed with a proper heat treatment process have attracted much attention. Compared with conventional nanoparticle photocatalysts prepared through complex chemical synthesis, the electrospinning method is direct and simple, and the prepared ceramic fibers possess a uniform morphology, high aspect ratio, large surface-to-volume ratio, 3D open structure, and rich surface active sites [2]. All these characteristics contribute to the enhanced photocatalytic activity and recovery rate of photocatalysts. Moreover, various strategies to optimize the performance of photocatalysts, such as doping, up-conversion illumination, and heterostructure and composite design, can be easily realized during electrospinning by simply changing the precursor prescription, electrospinning parameters, or thermal treatment process. Therefore, taking advantage of flexibility, easy recycling, and low cost, electrospun ceramic fibers have great potential as high-performance photocatalysts.

The further application of photocatalytic technology is mainly restricted by two aspects: (1) the narrow light response range; and (2) the limited photogenerated carrier utilization. During the past decades, a variety of strategies have been employed to improve the photocatalytic efficiencies of electrospun ceramic fibers. To expand the range of light response and develop visible-light-response photocatalysts, doping [30], solid solutions [31], the surface plasma effect [32], and up-conversion luminescence [33] have been widely used. In terms of improving the carrier utilization, the separation of photogenerated carriers is usually promoted by designing the heterojunction structure [34], the surface defect $[35,36]$, and the facet effect and polarization $[37,38]$. These methods all can be realized in electrospun ceramic nanofibers, and we have developed a serial of novel ceramic fiber photocatalysts, including Ag-ZnO nanofibers [17], $\mathrm{ZnO}-\mathrm{ZnS}$ core-shell nanofibers [39], and carbon quantum dots- $\mathrm{TiO}_{2}$ nanofibers [40]. We believe that electrospun ceramics fibers have great potential for photocatalytic applications and a comprehensive review can promote further developments in such a challenging field. This review focuses on the main obstacles in photocatalysis, proposes targeted solutions, and summarizes recent progress on electrospun ceramic fiber photocatalysts.

\section{The Fundamental of Photocatalysis}

From the perspective of photochemistry, semiconductor photocatalysts can achieve the aims of degradation, water splitting, and hydrogen production by initiating a serial of redox reactions under irradiation $[2,18]$. However, these photo reactions strongly depend on the intrinsic physical properties of the semiconductor, including the band gap and band position [27,41,42]. As illustrated in Figure 1, only a semiconductor with a proper band gap $\left(E_{\mathrm{g}}\right)$ can absorb photons whose energy is equal to or greater than their band gap energy. Then, the electrons $\left(\mathrm{e}^{-}\right)$at the valance band $(\mathrm{VB})$ will be excited to the conduct band (CB), leaving an equal number of holes $\left(\mathrm{h}^{+}\right)$at the VB. The photogenerated $\mathrm{e}^{-}$ and $\mathrm{h}^{+}$at $\mathrm{CB}$ and $\mathrm{VB}$ hold different chemical potentials according to the band position and will participate in the subsequent reduction and oxidation reaction, respectively [43]. For example, if the chemical potential of VB is lower than that of $\mathrm{OH}^{-} / \cdot \mathrm{OH}$ reaction, the holes at $\mathrm{VB}$ can react with absorbed $\mathrm{OH}^{-}$and produce hydroxyl radicals with high oxidation activity for pollutant decomposition [44]. Similarly, when the CB holds a higher chemical potential than that of $\mathrm{H}^{+} / \mathrm{H}_{2}$, hydrogen can be generated with the assistance of photogenerated electrons [45]. During the photocatalytic processes, two issues should be noted. First, the band gap determines the range of the solar spectrum utilized by semiconductors, and wide band gap semiconductors such as $\mathrm{TiO}_{2}\left(E_{\mathrm{g}}=3.2 \mathrm{eV}\right)$ can only be excited by ultraviolet (UV) light, which occupies $4 \%$ of the solar spectrum. Second, the photogenerated $\mathrm{e}^{-}$and $\mathrm{h}^{+}$pairs recombine easily and rapidly, accompanied by heat or light emission. Therefore, developing visible-light-response semiconductor photocatalysts and improving the utilization of photogenerated carriers still pose great challenges. 


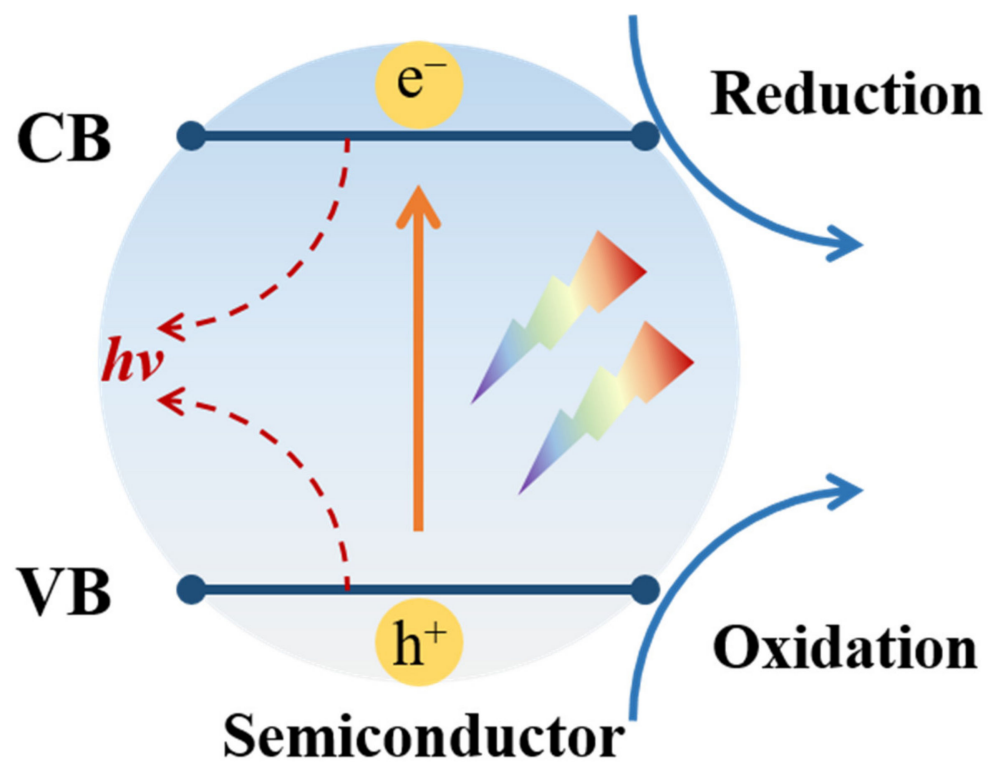

Figure 1. The diagram of semiconductor photocatalysis process.

Taking advantage of the high aspect ratio, good flexibility, proper surface area, and ease of recycling, 1D nanofibers are attractive for practical applications as photocatalysts $[46,47]$. For the production of high-quality 1D nanofibers, electrospinning has been widely considered as a simple, scalable, and cost-effective technology. Moreover, the two bottlenecks in photocatalysts, namely the visible light harvesting and carrier utilization, have been well resolved in numerous electrospun ceramic nanofibers, as listed in Table 1. Among these, various strategies are employed during the electrospinning process to adjust the solar energy absorption range, which is introduced in Section 3. Furthermore, different heterostructure designs and defective engineering have been realized in electrospun ceramic fibers to prolong the carrier lifetime, as discussed in Section 4.

Table 1. Summary of recent advances in ceramic fiber photocatalysts fabricated by electrospinning.

\begin{tabular}{|c|c|c|c|c|c|}
\hline Photocatalyst & Strategy & Light Source & Experimental Conditions & $\begin{array}{l}\text { Performance } \\
\text { Efficiency/Time }\end{array}$ & Reference \\
\hline $\mathrm{TiO}_{2}$ & Diameter control & UV lamp & $\begin{array}{c}\text { Catalyst: } 0.1 \mathrm{wt} . \% \\
\text { RhB: } 2.5 \times 10^{-5} \mathrm{~mol} / \mathrm{L}\end{array}$ & $\sim 90 \% / 20 \mathrm{~min}$ & [48] \\
\hline Bimetal-PANNM & Surface area & UV lamp & $\begin{array}{c}\text { Catalyst: } 4 \mathrm{~g} / \mathrm{L} \\
\text { Reactive blue 19: } 25 \mathrm{mg} / \mathrm{L}\end{array}$ & $100 \% / 80 \mathrm{~min}$ & [49] \\
\hline $\mathrm{CuWO}_{4}$ & Morphology & Visible light & $\begin{array}{l}\text { Catalyst: } 1 \mathrm{~g} / \mathrm{L} \\
\text { MO: } 5 \mathrm{mg} / \mathrm{L}\end{array}$ & $90 \% / 180 \mathrm{~min}$ & {$[50]$} \\
\hline $\mathrm{BiVO}_{4}$ & $\begin{array}{l}\text { Microstructure } \\
\text { (Hollow fibers) }\end{array}$ & Visible light & $\begin{array}{l}\text { Catalyst: } 0.5 \mathrm{~g} / \mathrm{L} \\
\text { Cr(VI): } 10 \mathrm{mg} / \mathrm{L}\end{array}$ & $95.3 \% / 80 \mathrm{~min}$ & [51] \\
\hline $\mathrm{ZnO}$ & $\begin{array}{c}\text { Defect } \\
\text { Microstructure }\end{array}$ & UV light & $\begin{array}{c}\text { Catalyst: } 1 \mathrm{~g} / \mathrm{L} \\
\text { MB: } 1.5 \times 10^{-5} \mathrm{~mol} / \mathrm{L}\end{array}$ & $90 \% / 85 \mathrm{~min}$ & [52] \\
\hline $\mathrm{Mn}^{2+} / \mathrm{ZnO}$ & Doping & Visible light & $\begin{array}{c}\text { Catalyst: } 1 \mathrm{~g} / \mathrm{L} \\
\text { RhB: } 2.5 \times 10^{-5} \mathrm{~mol} / \mathrm{L}\end{array}$ & $\sim 80 \% / 260 \mathrm{~min}$ & [53] \\
\hline $\mathrm{N}-\mathrm{Mn} / \mathrm{ZnO}$ & $\begin{array}{l}\text { Doping } \\
\text { Defect }\end{array}$ & Visible light & $\begin{array}{c}\text { Catalyst: } 1 \mathrm{~g} / \mathrm{L} \\
\text { RhB: } 2.5 \times 10^{-5} \mathrm{~mol} / \mathrm{L}\end{array}$ & $\sim 95 \% / 100 \mathrm{~min}$ & {$[54]$} \\
\hline $\mathrm{N}-\mathrm{TiO}_{2}$ & $\begin{array}{l}\text { Doping } \\
\text { Defect }\end{array}$ & Visible light & $\begin{array}{c}\text { Catalyst: } 0.1 \mathrm{wt} . \% \\
\text { RhB: } 2.5 \times 10^{-5} \mathrm{~mol} / \mathrm{L}\end{array}$ & $25 \% / 60 \mathrm{~min}$ & [55] \\
\hline$(\mathrm{ZnO})_{\mathrm{x}}(\mathrm{GaN})_{1-\mathrm{x}}$ & $\begin{array}{l}\text { Doping } \\
\text { Defect }\end{array}$ & Visible light & $\begin{array}{c}\text { Catalyst: } 1 \mathrm{~g} / \mathrm{L} \\
\mathrm{RhB}: 2.5 \times 10^{-5} \mathrm{~mol} / \mathrm{L}\end{array}$ & $\sim 100 \% / 80 \mathrm{~min}$ & [56] \\
\hline
\end{tabular}


Table 1. Cont.

\begin{tabular}{|c|c|c|c|c|c|}
\hline Photocatalyst & Strategy & Light Source & Experimental Conditions & $\begin{array}{l}\text { Performance } \\
\text { Efficiency/Time }\end{array}$ & Reference \\
\hline $\mathrm{Fe}-\mathrm{TiO}_{2} / \mathrm{SnO}_{2}$ & $\begin{array}{l}\text { Doping } \\
\text { Heterostructure }\end{array}$ & Visible light & $\begin{array}{c}\text { Catalyst: } 0.05 \text { wt. } \% \\
\text { RhB: } 2.5 \times 10^{-5} \mathrm{~mol} / \mathrm{L}\end{array}$ & $10 \% / 60 \mathrm{~min}$ & [57] \\
\hline $\mathrm{Au} / \mathrm{TiO}_{2}$ & $\begin{array}{l}\text { Surface plasmon } \\
\text { resonance }\end{array}$ & Visible light & $\begin{array}{l}\text { Catalyst: } 0.4 \mathrm{~g} / \mathrm{L} \\
\text { RhB: } 10 \mathrm{mg} / \mathrm{L}\end{array}$ & $42 \% / 120 \mathrm{~min}$ & {$[58]$} \\
\hline $\mathrm{Au} / \mathrm{g}-\mathrm{C}_{3} \mathrm{~N}_{4}$ & $\begin{array}{l}\text { Surface plasmon } \\
\text { resonance }\end{array}$ & LED light & $\begin{array}{c}\text { Catalyst: } 2 \text { cassettes } \\
\text { MB: } 5 \text { ppm }\end{array}$ & 90\%/50 min & [59] \\
\hline $\mathrm{TiO}_{2}$ & Phase junction & UV lamp & $\begin{array}{c}\text { Catalyst: } 1 \mathrm{~g} / \mathrm{L} \\
\mathrm{RhB}: 2.5 \times 10^{-5} \mathrm{~mol} / \mathrm{L}\end{array}$ & $\sim 100 \% / 40 \mathrm{~min}$ & {$[60]$} \\
\hline $\mathrm{BiVO}_{4}$ & Phase junction & Visible light & $\begin{array}{c}\text { Catalyst: } 1 \mathrm{~g} / \mathrm{L} \\
\text { RhB: } 2.5 \times 10^{-5} \mathrm{~mol} / \mathrm{L}\end{array}$ & $100 \% / 40 \mathrm{~min}$ & {$[61]$} \\
\hline $\mathrm{ZnO}-\mathrm{ZnS}$ & Heterostructure & UV lamp & $\begin{array}{c}\text { Catalyst: } 1 \mathrm{~g} / \mathrm{L} \\
\text { RhB: } 2.5 \times 10^{-5} \mathrm{~mol} / \mathrm{L}\end{array}$ & $73 \% / 60 \mathrm{~min}$ & [39] \\
\hline $\mathrm{g}-\mathrm{C}_{3} \mathrm{~N}_{4} / \mathrm{TiO}_{2}$ & Heterostructure & Visible light & $\begin{array}{l}\text { Catalyst: } 1 \mathrm{~g} / \mathrm{L} \\
\text { RhB: } 5 \mathrm{mg} / \mathrm{L}\end{array}$ & $\sim 75 \% / 120 \mathrm{~min}$ & {$[62]$} \\
\hline $\mathrm{ZnO}-\mathrm{TiO}_{2}-\mathrm{CNFs}$ & Heterostructure & UV lamp & $\begin{array}{c}\text { Catalyst: } 0.8 \mathrm{~g} / \mathrm{L} \\
\text { MB: } 10 \mathrm{ppm}\end{array}$ & 95\%/120 min & [63] \\
\hline $\mathrm{Ag}-\mathrm{ZnO}$ & Heterostructure & UV lamp & $\begin{array}{c}\text { Catalyst: } 1 \mathrm{~g} / \mathrm{L} \\
\text { RhB: } 2.5 \times 10^{-5} \mathrm{~mol} / \mathrm{L}\end{array}$ & $95 \% / 40 \mathrm{~min}$ & [17] \\
\hline $\mathrm{Ag} / \mathrm{BiVO}_{4}$ & Heterostructure & Visible light & $\begin{array}{c}\text { Catalyst: } 1 \mathrm{~g} / \mathrm{L} \\
\text { RhB: } 2.5 \times 10^{-5} \mathrm{~mol} / \mathrm{L}\end{array}$ & $\sim 100 \% / 20 \mathrm{~min}$ & {$[64]$} \\
\hline $\mathrm{TiO}_{2} / \mathrm{SnO}_{2}$ & Heterostructure & UV lamp & $\begin{array}{c}\text { Catalyst: } 0.1 \text { wt. } \% \\
\text { RhB: } 2.5 \times 10^{-5} \mathrm{~mol} / \mathrm{L}\end{array}$ & $90 \% / 60 \mathrm{~min}$ & {$[65]$} \\
\hline $\begin{array}{l}\mathrm{Ag}_{3} \mathrm{PO}_{4}-\mathrm{TiO}_{2-} \\
\quad \mathrm{CNFs}\end{array}$ & Heterostructure & Visible light & $\begin{array}{l}\text { Catalyst: } 0.5 \mathrm{~g} / \mathrm{L} \\
\text { MB: } 10 \mathrm{ppm}\end{array}$ & $100 \% / 10 \mathrm{~min}$ & {$[66]$} \\
\hline Carbon-CdS/ $\mathrm{TiO}_{2}$ & Heterostructure & Visible light & $\begin{array}{l}\text { Catalyst: } 0.5 \mathrm{~g} / \mathrm{L} \\
\text { MB: } 10 \text { ppm }\end{array}$ & $100 \% / 30 \mathrm{~min}$ & [67] \\
\hline $\mathrm{Bi}_{2} \mathrm{O}_{3} / g-\mathrm{C}_{3} \mathrm{~N}_{4}$ & Heterostructure & LED light & $\begin{array}{c}\text { Catalyst: } 0.25 \mathrm{~g} / \mathrm{L} \\
\text { TC: } 20 \mathrm{mg} / \mathrm{L}\end{array}$ & $\sim 60 \% / 3 \mathrm{~h}$ & {$[68]$} \\
\hline Co-CdSe@ECNFs & $\begin{array}{l}\text { Heterostructure } \\
\text { Doping }\end{array}$ & Visible light & $\begin{array}{l}\text { Catalyst: } 1 \mathrm{~g} / \mathrm{L} \\
\mathrm{MB}: 10 \mathrm{mg} / \mathrm{L}\end{array}$ & $87 \% / 90 \mathrm{~min}$ & [69] \\
\hline $\mathrm{ZnIn}_{2} \mathrm{~S}_{4} / \mathrm{SnO}_{2}$ & $\begin{array}{l}\text { Heterostructure } \\
\text { Microstructure }\end{array}$ & Visible light & $\begin{array}{l}\text { Catalyst: } 0.6 \mathrm{~g} / \mathrm{L} \\
\mathrm{Cr}(\mathrm{VI}): 50 \mathrm{ppm}\end{array}$ & $100 \% / 80 \mathrm{~min}$ & {$[70]$} \\
\hline $\mathrm{TiO}_{2} @ \mathrm{Ag} @ \mathrm{Cu}_{2} \mathrm{O}$ & $\begin{array}{l}\text { Heterostructure } \\
\text { Surface plasmon } \\
\text { resonance }\end{array}$ & Visible light & $\begin{array}{l}\text { Catalyst: } 0.5 \mathrm{~g} / \mathrm{L} \\
\text { MB: } 10 \mathrm{mg} / \mathrm{L}\end{array}$ & $99 \% / 90 \mathrm{~min}$ & {$[71]$} \\
\hline $\mathrm{ZnFe}_{2} \mathrm{O}_{4} / \mathrm{Ag} / \mathrm{AgBr}$ & $\begin{array}{l}\text { Heterostructure } \\
\text { Surface plasmon } \\
\text { resonance }\end{array}$ & LED light & $\begin{array}{l}\text { Catalyst: } 1 \mathrm{~g} / \mathrm{L} \\
\text { RhB: } 100 \mathrm{mg} / \mathrm{L}\end{array}$ & $86 \% / 100 \mathrm{~min}$ & {$[72]$} \\
\hline CQDs- $\mathrm{TiO}_{2}$ & $\begin{array}{l}\text { Up-conversion } \\
\text { luminescence } \\
\text { Heterostructure }\end{array}$ & Visible light & $\begin{array}{c}\text { Catalyst: } 1 \mathrm{~g} / \mathrm{L} \\
\text { RhB: } 2.5 \times 10^{-5} \mathrm{~mol} / \mathrm{L}\end{array}$ & $100 \% / 20 \mathrm{~min}$ & {$[40]$} \\
\hline
\end{tabular}

\section{Ceramic Nanofibers for Visible-Light Harvesting}

\subsection{Principles of Electrospinning Ceramic Fibers}

The setup of an electrospinning device is not complicated; typically, a high-voltage resource, syringe, metallic needle, and a grounded collector are enough [46], as shown in Figure 2. The precursor solution used for electrospinning should be uniform, nonconductive, and have an appropriate viscosity. Deionized water or ethanol are common 
solvents for precursor solutions, polymer provides a fiber skeleton and adjusts the solution's viscosity, and soluble metal salt determines the composition of the product ceramic fibers. Direct current (DC) and alternating current (AC) power are both suitable for electrospinning [73]. The spinneret is connected to a syringe containing precursor solution. By placing the syringe vertically, the precursor solution can flow through the spinneret under gravity. In addition, using a syringe pump is an effective means to control the flow rate of the precursor solution. When a high voltage is applied, the pendant drop of precursor polymer solution at the spinneret becomes highly electrified and is then distorted into a Taylor cone under the electrostatic interactions. Once the electrostatic forces overcome the surface tension of the precursor solution, a liquid jet is ejected from the needle. This electrified jet then undergoes a whipping and solvent evaporation process, leading to the reduction in the fiber's diameter from hundreds of micrometers to tens of nanometers [3]. Eventually, a non-woven fabric can be easily collected at the collector. For ceramic fibers, a subsequent thermal treatment process is needed to remove the polymer skeleton and other additives in the precursor solutions and obtain a well-crystallized structure.

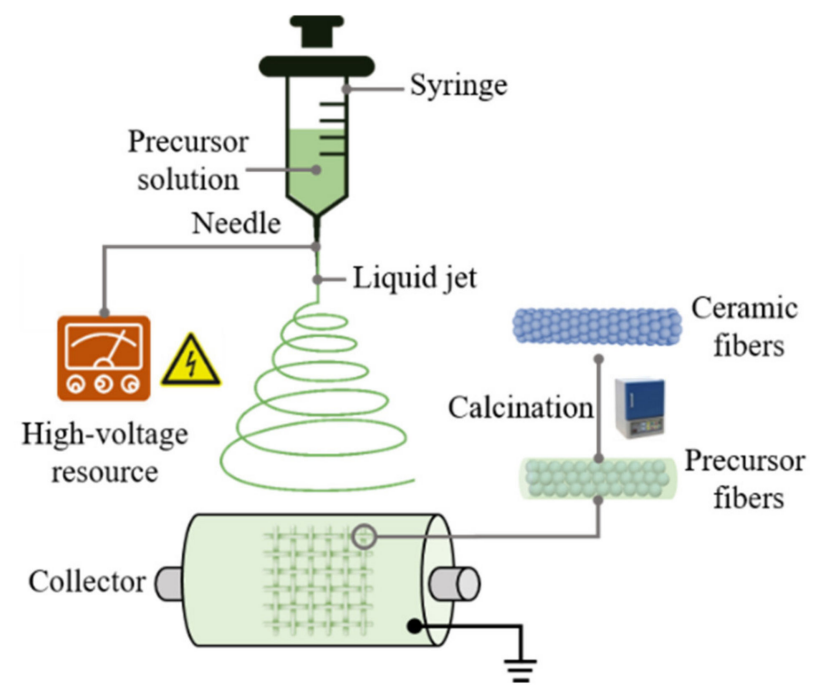

Figure 2. Schematic for the preparation of ceramic fibers by electrospinning.

Although the setup for electrospinning is simple, its mechanism is intricate and involves several physical instability processes [1]. Before 1999, the formation of nanofibers by electrospinning was ascribed to the repulsion of the charged liquid jet [74]. Now, experimental observations, electro-hydrodynamic theories, and mathematical model calculations all demonstrate that the thinning of a jet during electrospinning is mainly caused by the bending instability associated with the electrified jet [3,75-77]. In addition, its stability is determined by the electrostatic interactions between the external electric field and the polarized polymer solution [78-80]. The fibers with fine diameters can therefore be generated stably after the stretching and acceleration of the filament in the instability region. All these studies provide a better understanding of the electrospinning process and guidance for experimental design. By regulating the precursor composition, precursor viscosity, spinneret structure, electric field strength, and heat-treatment process, the morphology and microstructure of the prepared ceramic fibers can be finely designed and controlled. It is clear that electrospinning is an ideal choice for generating 1D nanostructures. However, many technical limitations still need to be resolved. First, electrospinning cannot effectively and quickly produce functional nanofibers for industrial manufacturing. Second, the location of fiber deposition is not easy to accurately control. Third, the production of separated fibers, especially single continuous long fibers, is hard to realize by electrospinning. Moreover, the strength of ceramic fibers is relatively low, and their mechanical properties need to be further optimized. Moreover, more studies are required in order to achieve a better control over the morphology and size of electrospun ceramic fibers. Nonetheless, 
electrospun ceramic fiber has achieved tremendous progress in recent years and shown application prospects in many fields, and particularly in that of photo catalysis.

For example, titanium dioxide is a pioneer of electrospun ceramic fiber photocatalysts, and is also a popular, excellent, and commercialized photocatalyst [43,81,82]. Li et al. selected tetrabutyl titanate, polyvinylpyrrolidone (PVP, $\mathrm{Mw}=1,300,000), \mathrm{H}_{2} \mathrm{O}$, and acetic acid as starting materials, and calcinated the precursor fibers at $400{ }^{\circ} \mathrm{C}$ for $2 \mathrm{~h}$ in air to obtain anatase $\mathrm{TiO}_{2}$ nanofibers [48]. They found that the diameter of the nanofibers, controlled by changing the tetrabutyl titanate content in the precursor solution, played an important role in the photocatalytic activity of $\mathrm{TiO}_{2}$ nanofibers. With a decrease in the diameter from 245 to $205 \mathrm{~nm}$, the photocatalytic activity of the $\mathrm{TiO}_{2}$ nanofiber is improved. However, further reduction in the diameter below $205 \mathrm{~nm}$ results in a deterioration in the photocatalytic activity, as shown in Figure 3. The $\mathrm{TiO}_{2}$ nanofibers with a diameter around $200 \mathrm{~nm}$ show a better performance, which is comparable with that of the commercial $\mathrm{TiO}_{2}$ photocatalyst nanopowders (P-25, Degussa Co., Ltd., Shanghai, China). In addition to $\mathrm{TiO}_{2}, \mathrm{ZnO}$ is also a representative photocatalytic material with a direct band gap $\left(E_{\mathrm{g}}=3.4 \mathrm{eV}\right)$, strong oxidation ability, and a large excitation binding energy, and can also be electrospun into nanofibers. Lin et al. prepared $\mathrm{ZnO}$ nanofibers by electrospinning and demonstrated its good photocatalytic property under UV light irradiation [17]. However, $\mathrm{TiO}_{2}$ and $\mathrm{ZnO}$ ceramic fibers need to absorb UV light to initiate the photocatalytic process. The search for novel visible-light-response ceramic fiber photocatalysts has been the main research trend in recent years.
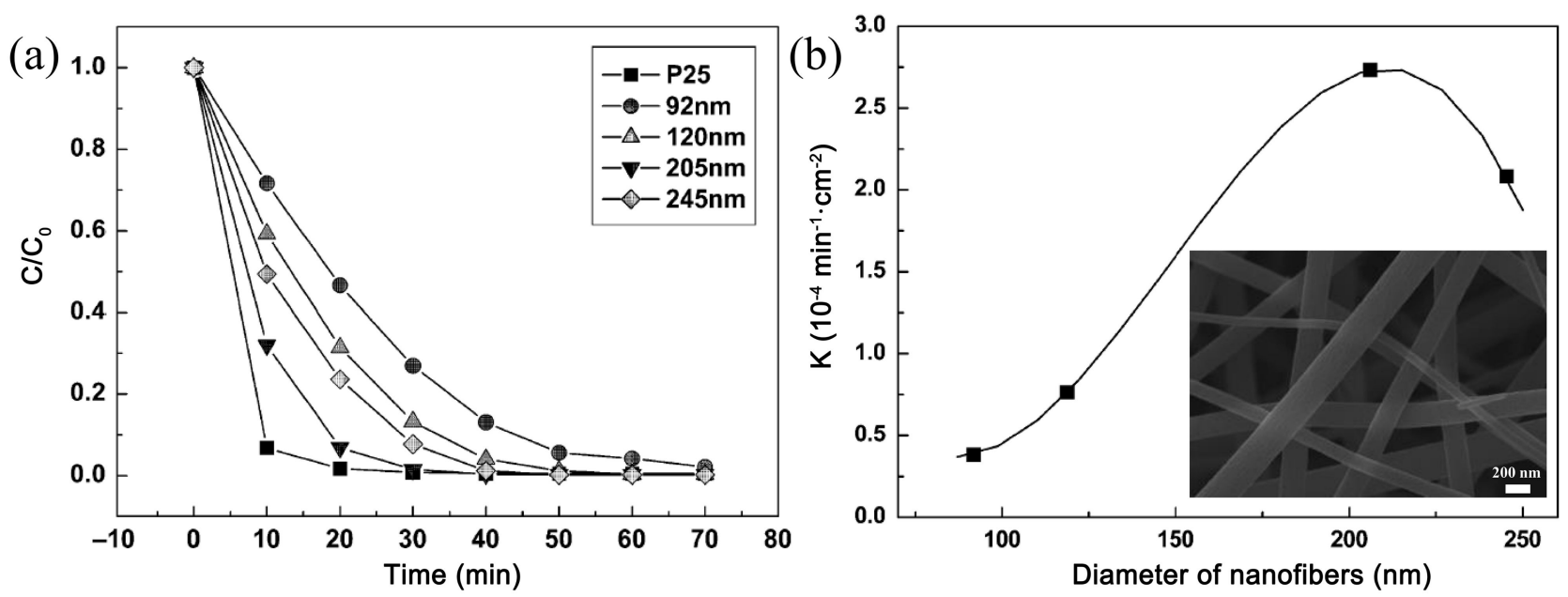

Figure 3. (a) Degradation of rhodamine $\mathrm{B}$ dye by $\mathrm{TiO}_{2}$ nanofibers with different diameters under UV light; (b) the relationship between the reaction rate constant and the diameter of $\mathrm{TiO}_{2}$ nanofibers (redrawn with the permission of Ref. [48]. Copyright 2010 John Wiley and Sons).

\subsection{Visible Light Responsive Ceramic Nanofibers}

Efficient utilization of solar energy is essential for photocatalysts. The solar energy reaching the surface of the Earth $\left(1.3 \times 10^{5} \mathrm{TW}\right)$, in which visible light is abundant, exceeds the global human energy consumption (16 TW) by nearly four orders of magnitude [18,83]. However, most of the semiconductor photocatalysts can only absorb ultraviolet light, which occupies $4 \%$ of the solar spectrum due to their wide band gaps. Therefore, to make better use of solar energy, it is important to identify a suitable semiconductor with a narrow band gap that can respond in the ultraviolet to visible wavelength range.

In recent years, a large amount of research has been devoted to finding visible-lightresponse photocatalysts, such as $\mathrm{BiVO}_{4}$ [64], $\mathrm{Bi}_{2} \mathrm{WO}_{6}$ [84], $\mathrm{AgNbO}_{3}$ [85], $\mathrm{AgVO}_{3}$ [86], $\mathrm{Ag}_{3} \mathrm{VO}_{4}$ [87], $\mathrm{Ag}_{3} \mathrm{PO}_{4}$ [66], CdS [67], $\mathrm{V}_{2} \mathrm{O}_{5}$ [88], and $\mathrm{InVO}_{4}$ [89]. Due to the formation of a continuous $\mathrm{VB}$ by Bi $6 s$, Ta $5 d$, or $\mathrm{V} 3 d$ orbitals, these photocatalysts have a narrow band gap and can absorb visible light for photocatalysis. Fortunately, these promising 
visible-light-responsive materials can also be synthesized conveniently by electrospinning. Cheng et al. used bismuth nitrate, ammonium vanadate, citric acid, and PVP to prepare the precursor solution, and fabricated tetragonal sheelite (s-t) and monoclinic sheelite (s-m) phase $\mathrm{BiVO}_{4}$ nanofibers for the first time by electrospinning [61]. The band gap of the prepared $\mathrm{BiVO}_{4}$ nanofibers was around $2.55-2.58 \mathrm{eV}$, which is suitable for visible light irradiation. The results of $\mathrm{RhB}$ degradation demonstrated that more than $70 \% \mathrm{RhB}$ was degraded by both single s-t and s-m phase $\mathrm{BiVO}_{4}$ nanofibers after $40 \mathrm{~min}$ visible light irradiation. A mat comprising electrospun $\mathrm{Bi}_{2} \mathrm{WO}_{6}$ nanofibers with a band gap of $2.68 \mathrm{eV}$ exhibited enhanced photocatalytic activity in the decomposition of $\mathrm{CH}_{3} \mathrm{CHO}$ for $\mathrm{CO}_{2}$ evaluation. Shang et al. proposed that the hybridization of the $\mathrm{Bi} 6 s$ and $\mathrm{O} 2 p$ largely dispersed the $\mathrm{VB}$, which facilitated the transfer of the generated charge carriers, thereby enhancing the photocatalytic oxidation of organic pollutants [90]. Although some achievements have been made in the search for visible-light-responsive materials, if the light absorption range of visible-light-responsive materials can be further expanded, or the light absorption range of ultraviolet-responsive materials can be extended to the visible light range, the utilization of solar energy will be greatly increased.

\subsection{Approaches to Expand the Light Absorption Range}

The light-absorbing range, limited by the intrinsic band gap, determines the theoretical solar energy conversion efficiency of semiconductors. To date, significant efforts have been made to expand the light-absorbing range of semiconductor photocatalysts from UV light to visible light. Doping, surface plasmon resonance, and up-conversion fluorescence have been widely proven to be efficient approaches and can be realized in electrospun ceramic fiber photocatalysts when controlling the precursor composition, electrospinning parameters, and the thermal treatment process.

\subsubsection{Precursor Composition Design}

The precursor solution for electrospinning is composed of the soluble salt of target components, the polymer skeleton, and solvents. The choice of polymer, solvent system, and concentration have a great influence on the crystal structure, facet, and morphology of the electrospun ceramic fibers, thereby changing their photocatalytic performance. For example, Li et al. found that the diameter of titanium oxide fibers increases linearly with the increase in the concentration of tetrabutyl titanate $\left(\mathrm{Ti}(\mathrm{oBu})_{4}\right)$ in the precursor solution [48]. Because the catalytic performance is closely related to the fiber diameter, the concentration can be used to control the performance. Regarding the polymer skeleton, there are various subtle designs, such as carbon-based ceramic fibers [63,66,67], carbon quantum dot (CQD) composite fibers [40], metal modified polymer fibers [49], and polymer modified ceramic fibers [91], that have been realized in electrospun fiber photocatalysts. Polyaniline (PANI) modified $\mathrm{TiO}_{2}$ / polyacrylonitrile (PAN) composite nanofibers were prepared using a mixture of dimethylformamde (DMF) and $\mathrm{N}$-methyl-2-pyrrolidone (NMP) as solvents [91]. The authors found that the PANI modified $\mathrm{TiO}_{2} / \mathrm{PAN}$ nanofibers demonstrated a relatively strong absorption in the visible region, whereas the pure $\mathrm{PAN}, \mathrm{TiO}_{2}$ and $\mathrm{TiO}_{2} / \mathrm{PAN}$ nanofibers has no significant absorbing peak. Thus, up to $90 \%$ degradation of $\mathrm{MO}$ was achieved by the PANI modified $\mathrm{TiO}_{2} / \mathrm{PAN}$ nanofibers in less than $60 \mathrm{~min}$ in comparison with the neat nanofibers (about 10\%). Moreover, the choice of salt is also important. Instead of the normally used nitrate, Lv et al. utilized the organic salt (Vanadium(IV)oxy Acetylacetonate) to induce the electrospinning gradient effect [51]. Then, hollow fibrous $\mathrm{BiVO}_{4}$ could be fabricated by single-spinneret electrospinning without a template. Benefiting from the unique tubular structure, $\mathrm{BiVO}_{4}$ nanotubes possess a hollow interior, leading to strong light harvesting ability and better photocatalytic performance than solid $\mathrm{BiVO}_{4}$ nanofibers. The authors proposed that this gradient effect is not subject to the usage amount, ratio, or kind of as-employed salt, which can also be applied for the fabrication of other tubular ceramic photocatalysts. 
Furthermore, the form of liquid precursor is convenient for cation doping and solid solution design, and helps to uniformly disperse doped elements in the prepared ceramic fibers. Doping, including anion and cation doping, can tune the position of both $\mathrm{CB}$ and VB, thereby expanding the light absorbing range [92-95]. Cation doping, mainly metal ion doping, will introduce an impurity level in the semiconductor. Under light irradiation, the electrons at both the VB and impurity level can be excited to CB [96]. Transition metals, such as $\mathrm{V}, \mathrm{Fe}, \mathrm{Co}, \mathrm{Ni}, \mathrm{Cr}$, and $\mathrm{Mn}$, can use the $3 d$ orbital to build a $\mathrm{t}_{2 g}$ impurity level and let the absorption edge of semiconductor red shift [97-101]. For example, Zhang et al. prepared a $\mathrm{Fe}^{3+}$-doped $\mathrm{TiO}_{2} / \mathrm{SnO}_{2}$ necklace-structured nanofiber by electrospinning [57,65]. The doping element $\mathrm{Fe}^{3+}$ and hybrid component $\mathrm{SnO}_{2}$ were introduced into the precursor solution by adding $\mathrm{Fe}\left(\mathrm{NO}_{3}\right)_{3} \cdot 9 \mathrm{H}_{2} \mathrm{O}$ and $\mathrm{H}_{2} \mathrm{SnO}_{3}$ nanoparticles. The XRD results shown in Figure 5a proved that $\mathrm{Fe}$ was successfully doped into the $\mathrm{TiO}_{2}$ lattice with no third phase other than anatase and rutile appearing. They found that $\mathrm{TiO}_{2} / \mathrm{SnO}_{2}$ nanofibers with 0.5 at.\% Fe doping possess the best photocatalytic performance, which exceeded that of non-doped nanofibers by a factor of more than 3 (Figure $5 b$ ). The author proposed that the $3 d$ electron excitation of $\mathrm{Fe}^{3+}$ to the $\mathrm{TiO}_{2}$ conduction band can increase the visible light absorption, and thus enhance the photocatalytic performance. However, the impurity level also provides a recombination center for the photogenerated holes and electrons, which is not conducive to photocatalytic performance.

Through precursor solution design, the second phase particles can be introduced into the ceramic nanofibers, which can initiate surface plasmon resonance (SPR) [102-104]. The free electrons of the metal particles will resonate under light irradiation, resulting in strong visible light absorption [105]. Through this effect, the response range of semiconductor materials can be extended to visible light. $\mathrm{Au}, \mathrm{Pd}$, and $\mathrm{Ag} / \mathrm{AgBr}$ are widely used as surface plasmon co-catalysts. Duan et al. prepared a $\mathrm{Au} / \mathrm{TiO}_{2}$ nanofiber by electrospinning and demonstrated its photocatalytic activity by degradation of $\mathrm{RB}$ under visible light and nature light irradiation [58]. Gao et al. designed and fabricated the Z-scheme $\mathrm{Au} / \mathrm{TiO}_{2} / \mathrm{WO}_{3}$ nanofibers [106]. They proposed that the SPR effect of $\mathrm{Au}$ can promote charge separation and absorption of visible light.

Electrospun ceramic fibers can also use the up-conversion luminescence effect to enhance the solar energy utilization. Ceramic fiber photocatalysts, containing rare earth elements and carbon quantum dots (CQDs) with an up-conversion luminescence effect, can absorb visible or even near-infrared light and emit ultraviolet or visible light [107-109]. Through this quantum tailor effect, the light response range of semiconductor materials can be further expanded. By intelligently designing the preparation process, these functional components can be introduced into the electrospun ceramic fiber. For example, Cheng et al. designed a $\mathrm{CQD}-\mathrm{TiO}_{2}$ fiber photocatalyst based on the up-conversion luminescent effect [40]. This nanocomposite fiber was assembled by a simple electrospinning and impregnation process. First, $\mathrm{TiO}_{2}$ nanofibers were prepared by electrospinning and a subsequent calcination process. Then, glucose was converted to CQDs under the assistance of alkali and ultrasound. After immersing $\mathrm{TiO}_{2}$ nanofibers into the CQD solution, ultrasonic treatment began and the time was controlled to obtain the different thicknesses of carbon shells in which CQDs were dispersed (Figure 4a,b). Finally, a series of CQD-TiO ${ }_{2}$ fibers with carbon shells of about 1,2, and $5 \mathrm{~nm}$ were obtained and labeled as C1, C2, and C3, respectively. They found that CQDs can absorb the near-infrared light and convert it into visible or even ultraviolet light. Then, the light in the range of 350-450 nm can excite $\mathrm{TiO}_{2}$ to start the photocatalytic reaction, as shown in Figure 4c. Based on this, the CQD$\mathrm{TiO}_{2}$ nanocomposite fibers exhibited a remarkable enhancement in photocatalytic activity compared to commercial $\mathrm{TiO}_{2}$ powders (Degussa P25) and pure CQDs. The C2 samples had the best performance with complete $\mathrm{RhB}$ degradation achieved in $20 \mathrm{~min}$ of visible light irradiation (Figure $4 \mathrm{~d}$ ). Moreover, the $\mathrm{CQD}-\mathrm{TiO}_{2}$ nanofibers demonstrated good repeatability during four continuous cycles shown in Figure 4e. The author proposed that the photocatalytic activity of the $\mathrm{CQD}-\mathrm{TiO}_{2}$ nanofibers was highly enhanced by utilizing the rapid carrier separation via the carbon shells, up-conversion property of CQDs, and 
the heterostructure of $\mathrm{TiO}_{2}$ and amorphous carbon, as illustrated in Figure 4f. When the catalysts are illuminated by visible light with photon energy higher than the band gap of $\mathrm{TiO}_{2}$ and CQDs, electrons in the valance band can be excited to the conduction band with the generation of the same number of holes. Furthermore, the up-conversion property of CQDs enables the composite nanofiber to utilize more solar energy to increase the photocatalytic activity. Then, the photogenerated electrons and holes were separated through the intimate contact interface of $\mathrm{TiO}_{2}$ and carbon, and generated hydroxyl radical species and superoxide radical anions for the degradation of organic compounds. Their achievements indicate that the up-conversion effect can help the wide band gap photocatalysts expand the light absorption range which is also easily realized by electrospinning.

(a)

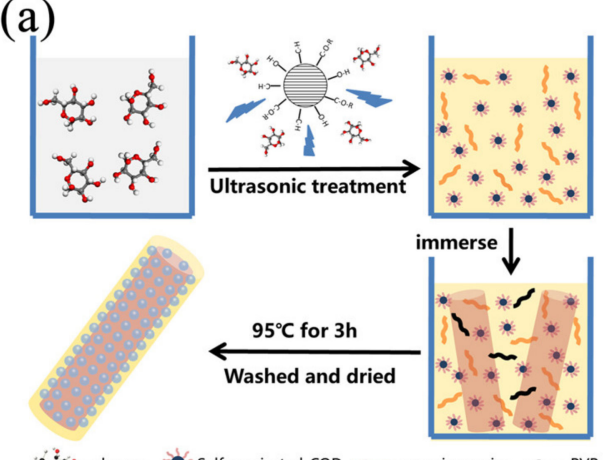
$\therefore$ glucose Self-passivated CQD $\sim$ organic species $\sim$ PVP
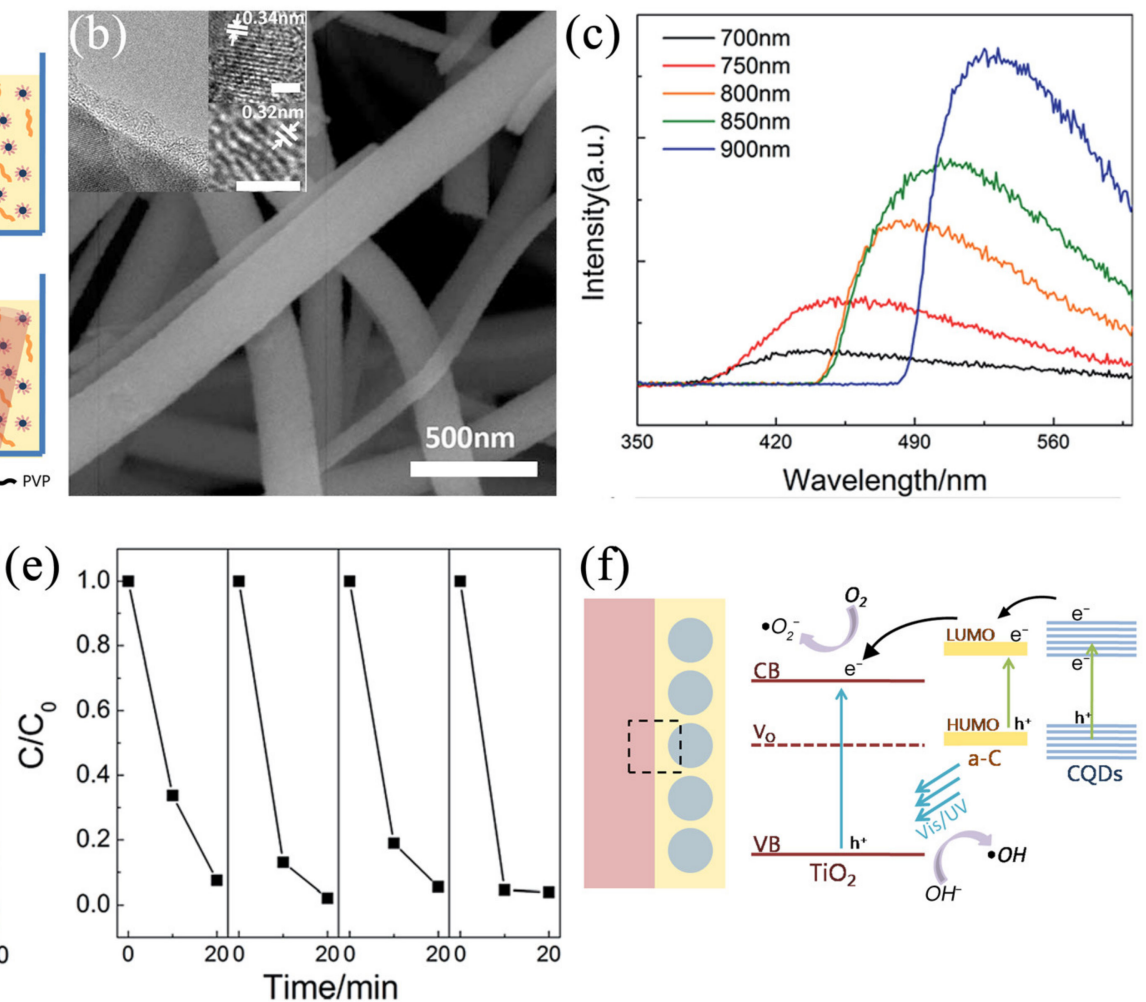

(f)

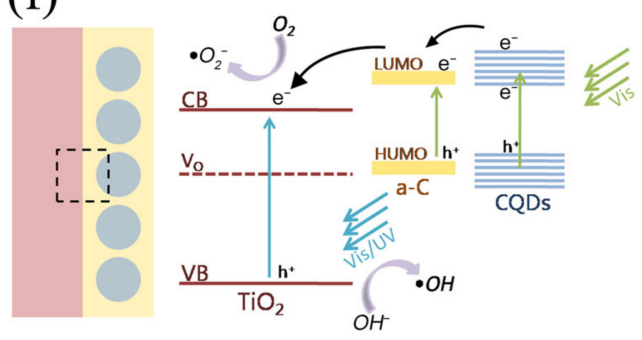

Time/min

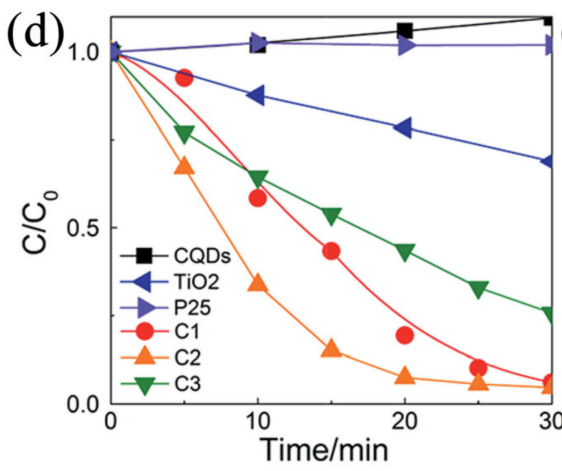

Figure 4. (a) Schematic illustration for the synthesis process; (b) the morphology of the $\mathrm{CQD}^{-\mathrm{TiO}} \mathrm{O}_{2}$ nanofibers; (c) the up-conversion properties of the CQDs; (d) photodegradation of RhB by the $\mathrm{CQD}-\mathrm{TiO}_{2}$ nanofibers under visible light irradiation; (e) the repeatability tests; (f) schematic illustration of the photocatalytic mechanism of the heterostructure. (Redrawn with the permission of Ref. [40]. Copyright 2017 The Royal Society of Chemistry).

\subsubsection{Electrospinning Parameters}

After completing the blend of the precursor solution, the variety of resulting fiber architectures becomes even greater with spinning parameter design. The main parameters are spinneret structure, number of nozzles, applied voltage, and tip to collector distance. By controlling the voltage and tip to collector distance, the intensity and distribution of the electrostatic field can be changed. Then, various microstructure containing soft surface, rough surface and beaded structure can be obtained in electrospun ceramic fibers. Lin et al. found that the jet diameter was a strong function of the applied voltage and the nozzle-toground distance and the formation of beads structure appeared with the increase in applied voltage [10]. Coaxial electrospinning is used for the preparation of core-shell nanofibers and hollow nanotubes [110]. In a typical coaxial electrospinning process, two concentric stainless steel needles are used for the inner capillary and outer tube to maintain the simultaneous separate feeding of two fluids. For example, $\mathrm{TiO}_{2}$ nanotubes were fabricated by coaxial electrospinning using the PVP solution as the core fluids and $\mathrm{TiO}_{2}$ sol as the shell [111]. Chang et al. analyzed the photocatalytic performance of hollow $\mathrm{TiO}_{2}$ nanotubes 
and solid $\mathrm{TiO}_{2}$ nanofibers by $\mathrm{MB}$ degradation and confirmed the superior performance of hollow $\mathrm{TiO}_{2}$ nanotubes [111]. The morphology and microstructure of the electrospun ceramic nanofibers can influence the light absorption, surface area, and surface active sites, such as the interior light interaction in hollow fibers, which enhances the light harvesting. Therefore, manipulating the microstructure of ceramic fibers during the electrospinning process by parameter control is an effective way to improve the photocatalytic performance.

\subsubsection{Heat Treatment Process}

Heat treatment of electrospun precursor fibers is a key step to obtaining a ceramic fiber with good crystallization, controllable crystal phase, adjustable defects, and proper band gap. Calcination temperature, heating program, and atmospheric conditions are the main parameters. For example, $\mathrm{Li}$ et al. prepared a series of $\mathrm{TiO}_{2}$ nanofibers with different phase ratios by controlling the calcination temperature [60]. Wang et al. calcinated the precursor fibers under $\mathrm{NH}_{3}$ to prevent the transfer of the doping element $\mathrm{Mn}^{2+}$ to $\mathrm{Mn}^{4+}$ and synthesized a visible-light-response $\mathrm{Mn}-\mathrm{ZnO}$ ceramic fiber photocatalyst [53]. Atmosphere sintering can also generate anion doping and surface defects, which have a great influence on photocatalytic activity. To date, (oxy)sulphides and (oxy)nitrides photocatalysts, such as $\mathrm{TaON}$ [112], $\mathrm{Ta}_{3} \mathrm{~N}_{5}$ [113], $\mathrm{Cu}_{2} \mathrm{ZnSnS}_{4}$ [114], AlON [115], $\mathrm{ZnIn}_{2} \mathrm{~S}_{4}$ [116], CdZnS [117], and $\mathrm{Bi}_{2} \mathrm{O}_{2} \mathrm{~S}$ [118], have attracted ongoing interest due to their narrow band gaps and suitable band position. In contrast to introducing an impurity level by metal doping, as mentioned previously, N $2 p$ and S $3 p$ orbitals can help to form a valence band at potentials more negative than those of $\mathrm{O} 2 p$ orbitals, resulting in a narrow band gap. Electrospinning can also be used to fabricate oxynitride nanofibers by controlling the calcination atmospheres. $\mathrm{Li}$ et al. annealed the electrospun $\mathrm{TiO}_{2}$ nanofibers under $\mathrm{NH}_{3}$ atmosphere and obtained surface nitride $\mathrm{N}-\mathrm{TiO}_{2}$ nanofibers (Figure 15a) [55]. Compared with pure $\mathrm{TiO}_{2}$ nanofibers that can only be irradiated by UV light, the oxynitride nanofibers demonstrated good photocatalytic performance for RhB decomposition under visible light, as shown in Figure 15b. The author proposed that $\mathrm{N}$-doping helps to expand the light absorption range from UV to visible light, and that the nitride temperature plays a key role. It is seen in Figure $15 \mathrm{c}$ that the reaction rate constant $k$ of $\mathrm{RhB}$ degradation first increased with the nitridation temperature, then, when the temperature further increased above $500{ }^{\circ} \mathrm{C}, k$ decreased. The author proposed that this decrease in performance was ascribed to the formation of nonphotocatalytically active TiN phase. Cheng et al. prepared zinc-doped gallium oxynitride nanofibers by calcinating the electrospun $\mathrm{Zn}-\mathrm{Ga}-\mathrm{O}$ nanofibers under ammonia atmosphere [56]. The XRD results shown in Figure 6 confirm the formation of $\mathrm{Zn}$-doped gallium oxynitride phase. They found that the absorption edge and band gap were affected by the degree of nitridation (Figure $6 c, d$ ). Compared with pure GaN $(3.4 \mathrm{eV})$ and $\mathrm{ZnO}(3.2 \mathrm{eV})$, the band gap of oxynitride nanofibers was narrowed to around $2.7 \mathrm{eV}$ when annealed at $850^{\circ} \mathrm{C}$, and the light absorption range was expanded to the visible light region. As expected, the oxynitride nanofibers exhibited excellent photocatalytic performance.

It can be seen that the electrospun ceramic fibers possess excellent photocatalytic activity and are suitable for the water treatment process. Their performance usually exceeds the particle catalysts with the same composition and the commercial $\mathrm{TiO}_{2}$ under the same conditions. Moreover, the electrospun ceramic fibers can be recycled easily and demonstrate stable performance during continuous tests, avoiding the problems of the energy-consumption regeneration process, catalyst leakage, and secondary pollution. Although doping, surface plasmon resonance, the up-conversion luminescence effect, and morphology have been used to narrow the band gap of electrospun ceramic fiber photocatalysts and thus enlarge the light-harvesting range, enhancing visible light absorption is still of vital importance for the development of new photocatalysts. The rise of high-entropy (HE) materials has led to new research directions [119]. HE materials have demonstrated excellent performance in the fields of thermal protection and insulation, rechargeable batteries, electrocatalysis, etc. By forming solid solutions with multi-principal elements, the 
band structure and band gap of HE ceramic fibers can be tuned and may be expanded to the visible light range, enabling the fibers to become high-performance photocatalysts. Hu et al. designed a high-entropy metal oxide containing 10 metal elements and achieved significant results in the field of electrocatalysts for oxygen reduction reactions [120]. However, there have been no reports concerning the photocatalytic properties of HE ceramic fibers. In addition, other approaches to expand the light-absorbing range are also worth studying for electrospun ceramic fibers.
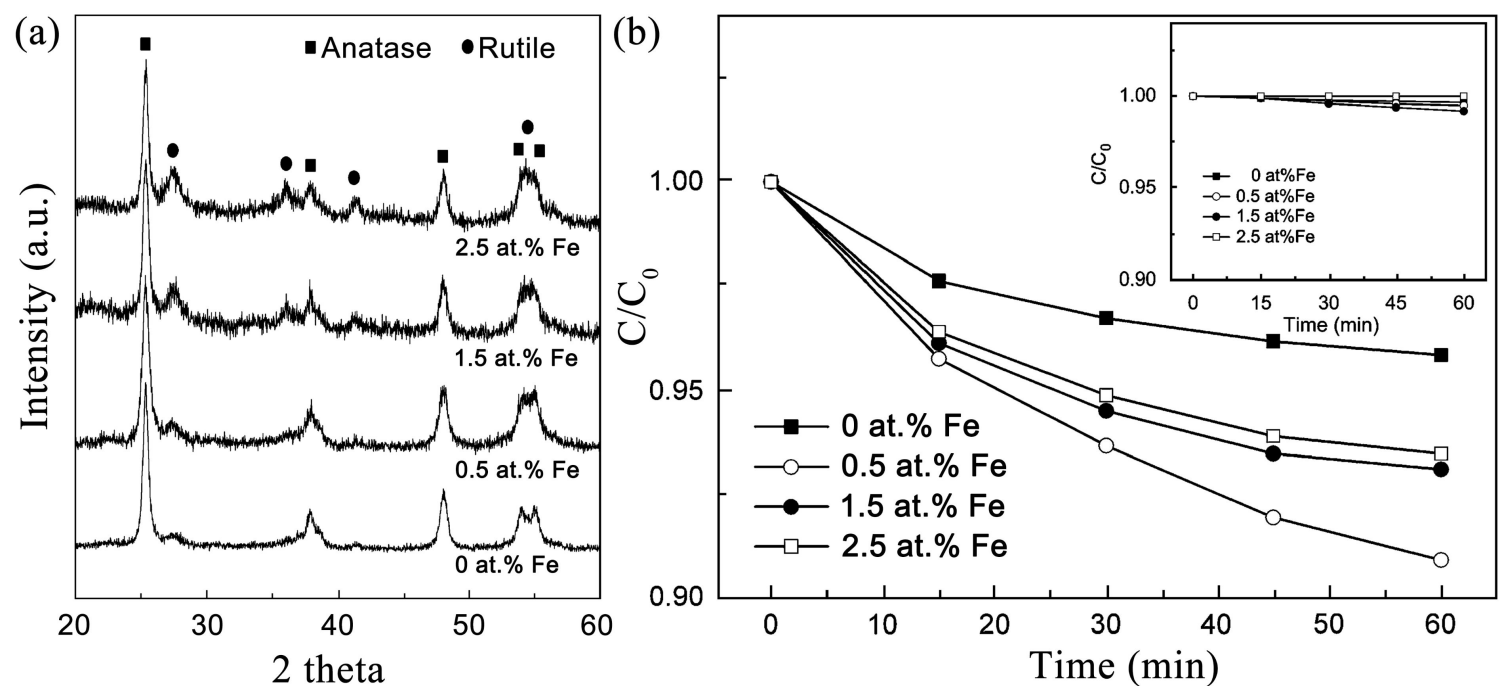

Figure 5. XRD results of $\mathrm{Fe}^{3+}$-doped $\mathrm{TiO}_{2} / \mathrm{SnO}_{2}$ nanofibers with different Fe content (a), and the degradation of $\mathrm{RhB}$ dye under visible light irradiation (b). Inset shows the adsorption of RhB on hybrid nanofibers. (Redrawn with the permission of Ref. [57]. Copyright 2010 John Wiley and Sons).
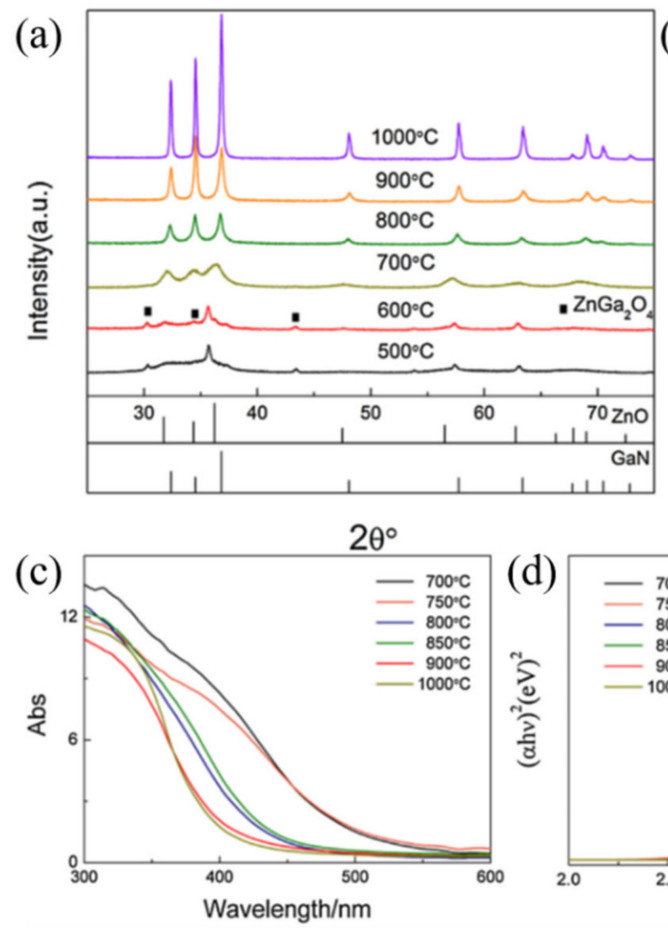

(b)

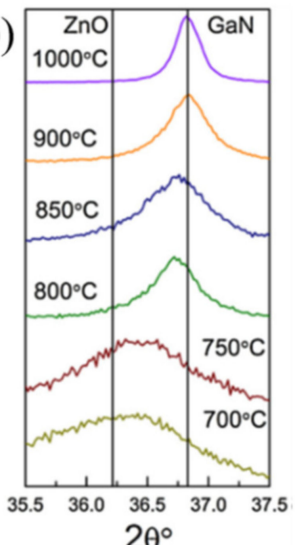

$2 \theta^{\circ}$

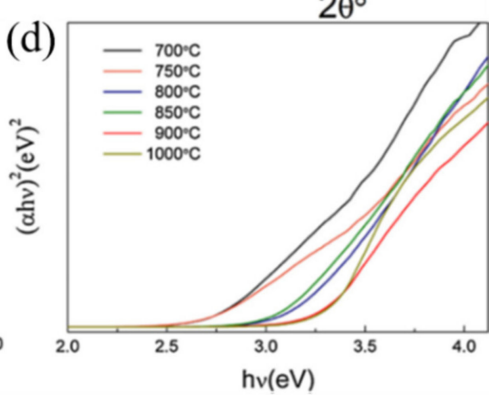

Figure 6. XRD patterns of samples calcined at different temperatures $(\mathbf{a}, \mathbf{b})$, UV-vis diffuse reflection spectra of the zinc-doped gallium oxynitride nanofibers calcined at different temperatures (c), and the corresponding plots of $(\alpha h v)^{2}$ vs. photon energy $(h v)(\mathbf{d})$. (Redrawn with the permission of Ref. [56]. Copyright 2017 Elsevier). 


\section{Ceramic Nanofibers for Efficient Carrier Separation}

When the light shines on electrospun ceramic fiber photocatalysts, electrons $\left(\mathrm{e}^{-}\right)$at the valance band $(\mathrm{VB})$ will be excited to the conduction band $(\mathrm{CB})$, leaving behind an equal number of holes $\left(\mathrm{h}^{+}\right)$at the $\mathrm{VB}$, as illustrated in Figure 1. Then, the photogenerated carriers move to the surface of ceramic nanofibers, and stimulate and participate in the subsequent redox reactions for water splitting, pollutant degradation, etc. These carriers are critical to photocatalytic efficiency. However, their lifetime is extremely short, accompanied by dynamic recombination and annihilation. Thus, extending carrier lifetime and improving its utilization is another great challenge. At present, heterojunction construction, morphology design, and defect engineering are the main methods to separate the carriers in electrospun ceramic nanofibers.

\subsection{Metal-Ceramic Heterojunction}

The introduction of well-dispersed metal particles into the electrospun ceramic fibers forms a metal-ceramic heterojunction. The rectifying characteristics of a metal-semiconductor system can provide an efficient and feasible pathway for carrier separation [121]. For example, if the metal with a higher work function contacts a semiconductor $\left(\varphi_{\mathrm{m}}>\varphi_{\mathrm{s}}\right)$, electrons will pass from the semiconductor into the metal to equalize the Fermi energy levels and bend the energy band upward [122], as illustrated in Figure 7a. This process will form a positively charged space layer called the Schottky barrier which can serve as an efficient electron trap and prevent the recombination of electron-hole pairs. Conversely, the electrons will flow from the metal to the $\mathrm{CB}$ of the semiconductor, leaving behind a negatively charged space layer in which the band is bent downward (Figure 7b). Under light irradiation, the photogenerated electrons of the semiconductor can transfer to metal through the space charge layer; thus, the carrier lifetime can be prolonged. Based on this theory, various metal-semiconductor systems have been designed and realized by electrospinning, such as $\mathrm{Ag}-\mathrm{ZnO}$ [17], $\mathrm{Ag}-\mathrm{BiVO}_{4}$ [64], $\mathrm{Ag}-\mathrm{BaTiO}_{3}$ [123], $\mathrm{Au}-\mathrm{TiO}_{2}$ [124], and $\mathrm{Pt} / \mathrm{Au}-\mathrm{BiVO}_{4}[125]$.

(a)

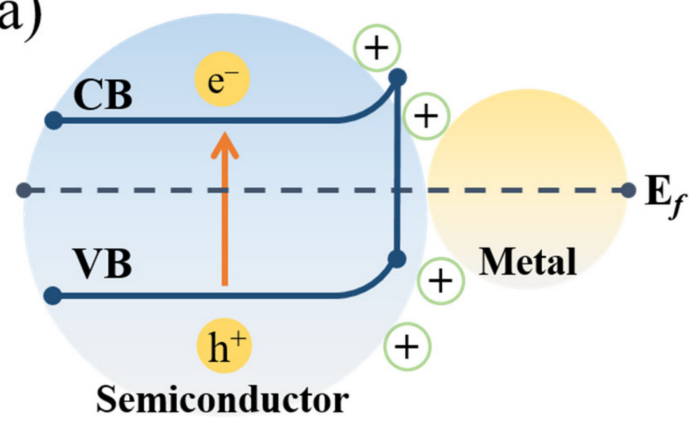

(b)

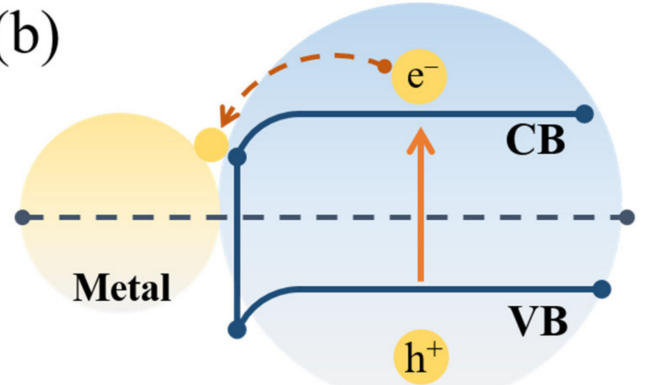

Semiconductor

Figure 7. The schematic of the metal-semiconductor heterojunction: (a) $\varphi_{\mathrm{m}}>\varphi_{\mathrm{s}}$ and (b) $\varphi_{\mathrm{m}}<\varphi_{\mathrm{s}}$.

Lin et al. added silver nitrate into the precursor solution and fabricated Ag- $\mathrm{ZnO}$ nanofibers by electrospinning [17]. During the electrospinning process, the precursor solution needed to be shaded to avoid decomposition of the silver nitrate. Furthermore, a plastic capillary was used as the spinneret, and the electric field was applied by dipping a charged silver thread directly into the precursor solution. They demonstrated that the Ag partials dispersed homogeneously along the $\mathrm{ZnO}$ nanofibers and formed a metalsemiconductor heterojunction (Figure 8a-d). Under UV light irradiation, the 7.5 at.\% $\mathrm{Ag}-\mathrm{ZnO}$ nanofibers exhibited better performance than $\mathrm{ZnO}$ nanofibers and commercial P25 with no decrease during the cycle tests, as shown in Figure 8e-h. The introduction of metal $\mathrm{Ag}$ facilitated the rapid transfer of the photogenerated electrons from $\mathrm{ZnO}$ to $\mathrm{Ag}$, extended the lifetime of electron-hole pairs, and enhanced the photocatalytic performance. 
However, due to the wide band gap of $\mathrm{ZnO}$, heterostructure design can only enhance the performance of $\mathrm{Ag}-\mathrm{ZnO}$ nanofibers in the UV light absorption range.
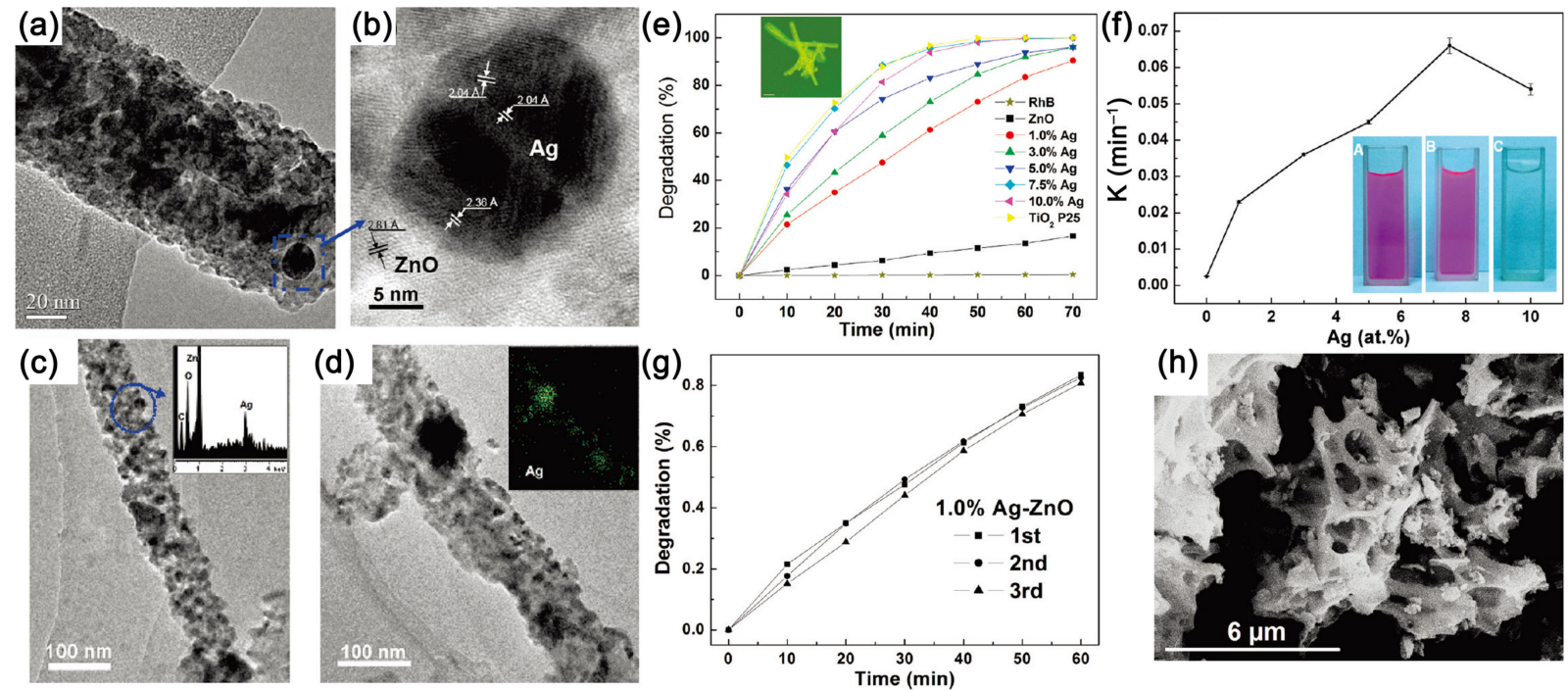

Figure 8. (a) The TEM image of 5.0 at.\% Ag-ZnO nanofibers; (b) HRTEM image from the squared region of part a; (c) TEM image of 7.5 at.\% Ag-ZnO nanofibers and EDX result on selected areas; (d) TEM image of 10 at.\% Ag-ZnO nanofibers and EDX mapping of Ag element along the nanowire; (e) kinetics and (f) photodegradation rate constant of RhB by Ag- ZnO nanofibers under UV light; (g) the cyclic performance; (h) the morphology of Ag-ZnO nanofibers after photocatalytic measurement. (Redrawn with the permission of Ref. [17]. Copyright 2009 American Chemical Society).

To achieve visible light photocatalysis, Cheng et al. selected $\mathrm{BiVO}_{4}$ with a narrow band gap to construct a novel heterojunction with $\mathrm{Ag}$ [64]. Ag-BiVO ${ }_{4}$ nanofibers with different Ag contents were fabricated by electrospinning. Then, their photocatalytic activity was determined by dye degradation under visible light. As shown in Figure 9a, the $\mathrm{RhB}$ degradation performance was improved compared with pure $\mathrm{BiVO}_{4}$ nanofibers by introducing $\mathrm{Ag}$ particles. The photocatalytic activity of $\mathrm{Ag}-\mathrm{BiVO}_{4}$ nanofibers increased with the increase in $\mathrm{Ag}$ content, and the composite fibers containing $10 \mathrm{at} . \% \mathrm{Ag}$ showed the best performance, with almost $100 \% \mathrm{RhB}$ degradation achieved in $20 \mathrm{~min}$. By band structure analysis, they proposed that the photogenerated electrons migrated from $\mathrm{CB}$ of $\mathrm{BiVO}_{4}$ to $\mathrm{Ag}$, impeding the recombination of photogenerated carriers (Figure 9b). Therefore, it is believed that the construction of a metal-ceramic junction can prolong the carrier lifetime and improve the photocatalytic properties of ceramic fibers.
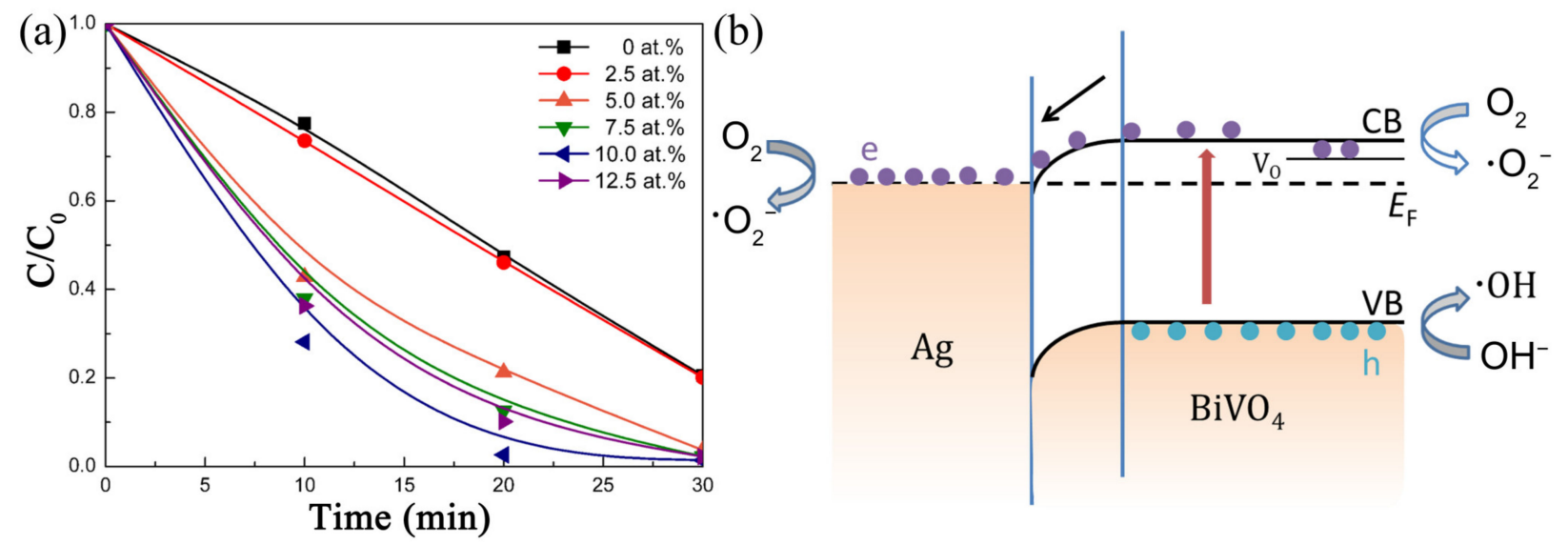

Figure 9. (a) The photocatalytic performance of $\mathrm{Ag}-\mathrm{BiVO}_{4}$ nanofibers under visible light irradiation; (b) the proposed mechanism. (Redrawn with the permission of Ref. [64]. Copyright 2018 Science Press). 


\subsection{Semiconductor-Semiconductor Heterojunction}

In addition to the metal-semiconductor heterojunction, the heterojunction composed of two kinds of semiconductor can also be constructed easily in the electrospun ceramic fibers by controlling the precursor solution and thermal treatment process. According to the different band structure, there are two types of semiconductor-semiconductor (S-S) heterojunction, as illustrated in Figure 10. In the T-1 junction, the $C B$ of semiconductor $A$ is lower than that of $B$, whereas its VB is higher than that of B. After light irradiation, the electron and hole will transfer to $\mathrm{A}$ and stimulate a series of redox reactions. For example, $\mathrm{Li}$ et al. developed a special T-1 junction composed of rutile $\mathrm{TiO}_{2}$ and anatase $\mathrm{TiO}_{2}$ [60]. The anatase-rutile heterostructured $\mathrm{TiO}_{2}$ ceramic nanofibers were prepared by electrospinning. The fraction of rutile phase was controlled by the annealing temperature. The RhB decomposition performance of the obtained nanofibers was strongly dependent on the calcination temperature. The nanofibers annealed at $600{ }^{\circ} \mathrm{C}$ with $3 \mathrm{wt} . \%$ rutile phases exhibited the optimal performance, as shown in Figure 11a. The authors proposed that the transfer of electrons from the $\mathrm{CB}$ of anatase $\mathrm{TiO}_{2}$ to a lower energy $\mathrm{CB}$ of rutile $\mathrm{TiO}_{2}$ can increase the lifetime of carriers and thus enhance the photocatalytic efficiency (Figure 11b).

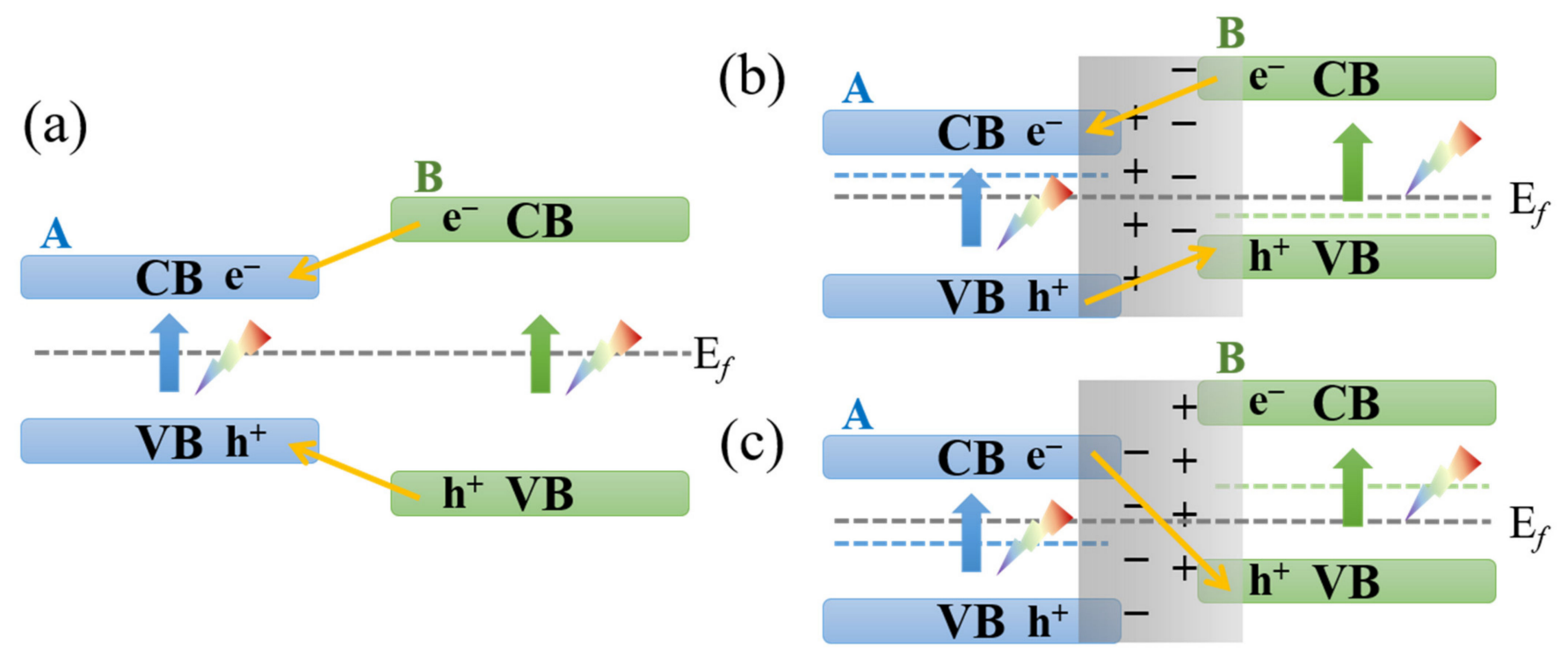

Figure 10. The illustration of semiconductor-semiconductor heterojunction type-1 (a) and type-2 (b,c), where A and B both represent semiconductors with different band structures.

Various ceramic fiber photocatalysts with a type 2 heterojunction have been developed in recent years, including $\mathrm{ZnO}-\mathrm{ZnS}$ core-shell nanofibers [39], tetragonal-monoclinic $\mathrm{BiVO}_{4}$ nanofiber [61], $\mathrm{MnO}-\mathrm{ZnO}$ nanofibers [53], $\mathrm{TiO}_{2}-\mathrm{SnO}_{2}$ nanofibers [65], $\mathrm{Ag}_{3} \mathrm{PO}_{4}-\mathrm{TiO}_{2}-$ CNFs [66], and Carbon-CdS/ $\mathrm{TiO}_{2}$ nanofibers [67]. In a type 2 (T-2) heterojunction, the $\mathrm{CB}$ and $\mathrm{VB}$ of $\mathrm{B}$ are both higher than that of $\mathrm{A}$, which can further derive two carrier transfer modes, as illustrated in Figure 10b,c. When the work function of component B is larger than that of A, a traditional T-2 heterojunction is formed and the electrons will flow from A to $B$ to equalize the Femi level. This charge transfer process will build an inner electric field at the interface, as shown in Figure 10b, and provide an opposite transfer route for photogenerated electrons and holes. For example, Lin et al. synthesized the $\mathrm{ZnO}-\mathrm{ZnS}$ core-shell nanofibers by electrospinning followed by a sulfurization process [39]. The thickness of the $\mathrm{ZnS}$ shell was controlled by the sulfurization reaction time (Figure 12a,b). They found that the $12 \mathrm{~h}$ sulfurization $\mathrm{ZnO}-\mathrm{ZnS}$ nanofibers exhibited the optimal photocatalytic performance with a $\mathrm{RhB}$ degradation rate of $0.024 \mathrm{~min}^{-1}$, which is 10 times higher than that of pure $\mathrm{ZnO}$, as shown in Figure 12c. They proposed that the $\mathrm{ZnO}$ and $\mathrm{ZnS}$ formed 
the T-2 type heterojunction (Figure 12d). Under UV light irradiation, the photogenerated electron of $\mathrm{ZnS}$ moved to the $\mathrm{CB}$ of $\mathrm{ZnO}$, and the holes at the $\mathrm{VB}$ of $\mathrm{ZnO}$ transferred to the VB of ZnS, as illustrated in Figure 12d. The reverse transmission of electrons and holes can increase the yield and lifetime of carries.
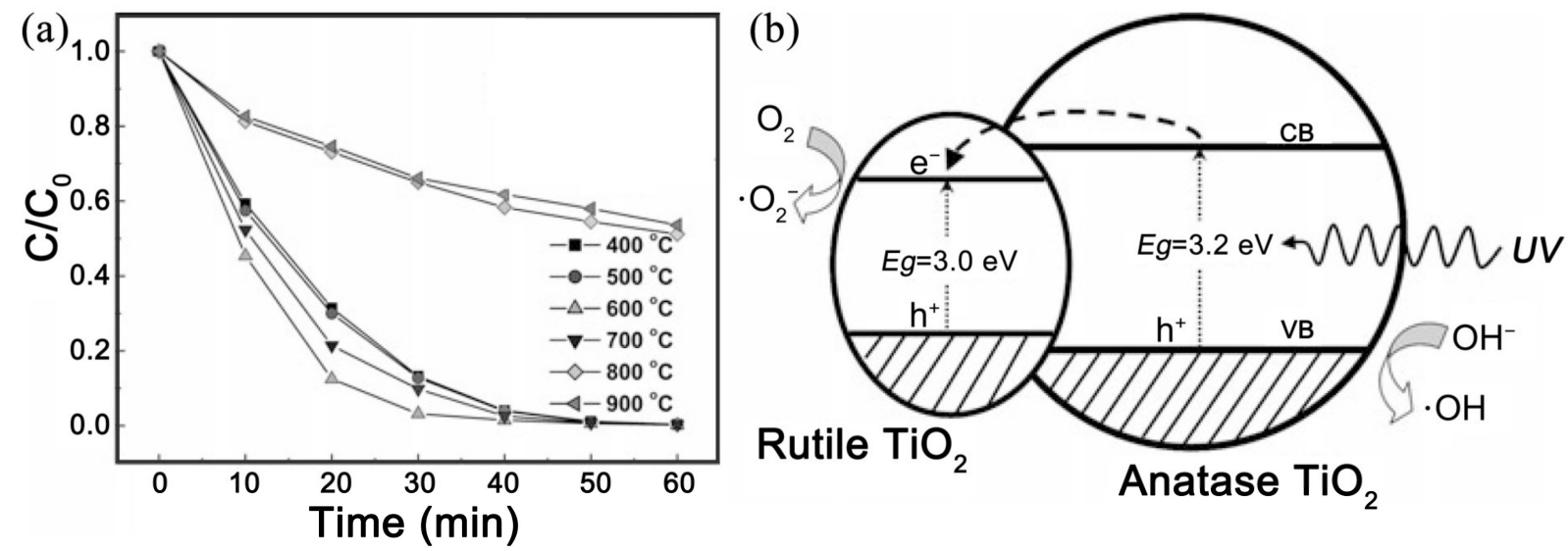

Figure 11. Photocatalytic performance (a) and proposed mechanism (b) of anatase-rutile heterostructured $\mathrm{TiO}_{2}$ ceramic nanofibers for dye degradation under UV light. (Redrawn with the permission of Ref. [60]. Copyright 2021 John Wiley and Sons).
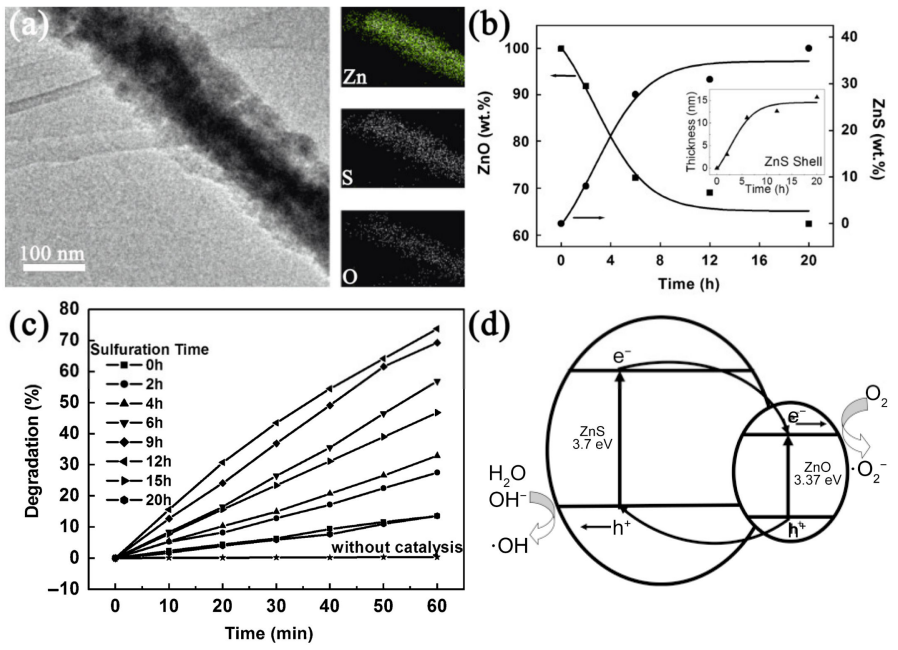

Figure 12. (a) The morphology and elementary distribution of ZnO-ZnS nanofibers; (b) dependence of phase contents on sulfuration times (inset shows the relationship between the thickness of the $\mathrm{ZnS}$ shell and the sulfurating time); (c) kinetics of the photodegradation of $\mathrm{RhB}$ by $\mathrm{ZnO}-\mathrm{ZnS}$ nanofibers that were sulfurized for various times; (d) proposed schematic illustration of the band structurerelated photocatalytic mechanism of the $\mathrm{ZnO}-\mathrm{ZnS}$ heterostructure nanofibers. (Redrawn with the permission of Ref. [39]. Copyright 2010 John Wiley and Sons).

For visible-light-response ceramic photocatalysts, Cheng et al. successfully prepared a novel $\mathrm{BiVO}_{4}$ nanofiber with tetragonal-monoclinic phase junction by electrospinning [61]. The phase ratio was controlled by the calcination temperature. The $\mathrm{BiVO}_{4}$ nanofibers calcinated at $450{ }^{\circ} \mathrm{C}$ exhibited the best photocatalytic activity under visible-light irradiation with an optimal rate constant and apparent quantum efficiency that was 10 times higher than that of the single tetragonal phase $\mathrm{BiVO}_{4}$ and 5 times higher than that of the monoclinic phase $\mathrm{BiVO}_{4}$ (Figure 13a-d). They revealed that the enhanced photocatalytic activity can be attributed to the T-2 type heterojunction formed in the electrospun tetragonal-monoclinic $\mathrm{BiVO}_{4}$ nanofibers, which prevented the recombination of electron-hole pairs and improved carrier utilization (Figure 13e). Similarly, the mechanism of the T-2 type heterojunction 
was also demonstrated in the $\mathrm{MnO}-\mathrm{ZnO}$ nanofibers [53] and $\mathrm{TiO}_{2}-\mathrm{SnO}_{2}$ nanofibers [65] prepared by electrospinning. On the basis of the T-2 type heterojunction, the introduction of carbon as a support has been proven to provide a unique benefit in suppressing the charge recombination. Carbon-coated ceramics nanofibers, such as $\mathrm{Ag}_{3} \mathrm{PO}_{4}-\mathrm{TiO}_{2}-\mathrm{CNFs}$ [66] and carbon-CdS/ $\mathrm{TiO}_{2}$ nanofibers [67], have been prepared by electrospinning and following the carbonization process, and present good photocatalytic performance.
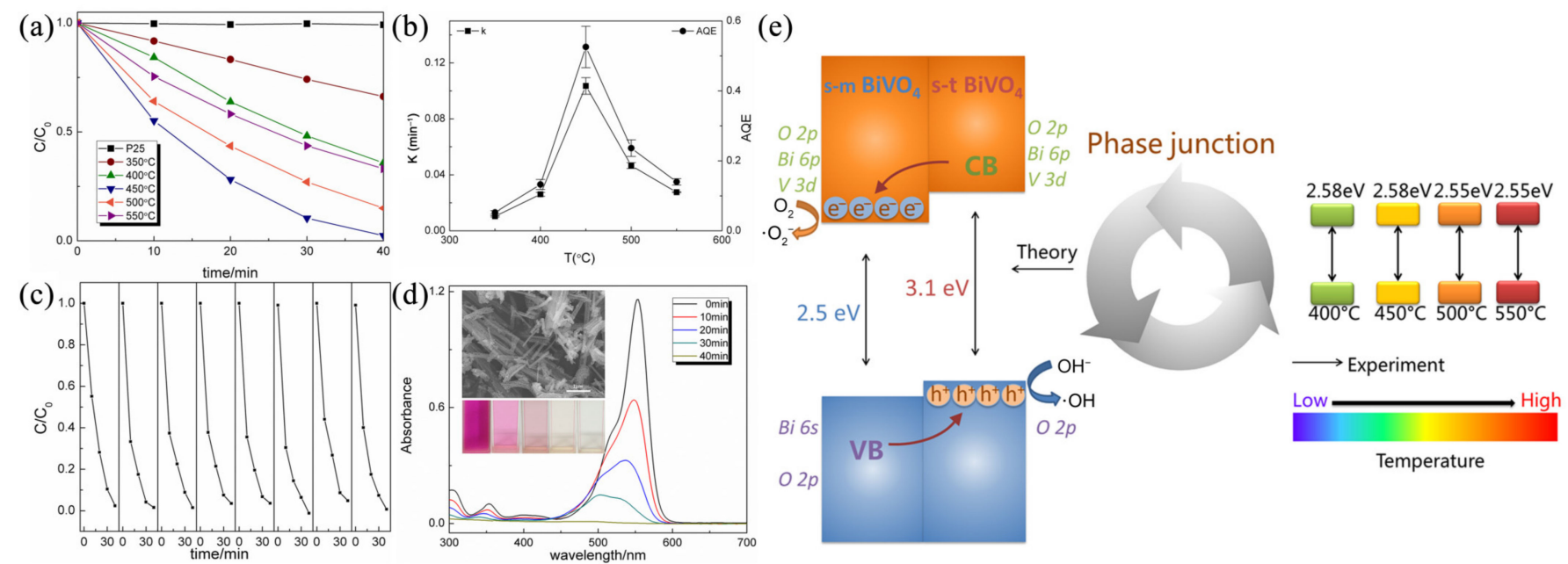

Figure 13. (a) Photodegradation of $\mathrm{RhB}$ by $\mathrm{BiVO}_{4}$ nanofibers calcined at different temperatures; (b) rate constants and apparent quantum efficiencies for $\mathrm{BiVO}_{4}$ nanofibers; (c) the repeatability tests of the specimen calcined at $450{ }^{\circ} \mathrm{C}$; (d) the absorption spectrum of the $\mathrm{RhB}$ solution in the presence of $\mathrm{BiVO}_{4}$ nanofibers. The inset illustrates photos of the RhB solutions photodegraded with different time and the SEM image of the specimen reclaimed after photocatalytic measurement; (e) schematic illustrations of the band structure-related photocatalytic mechanism for the s-m/s-t $\mathrm{BiVO}_{4}$ phase junction. (Redrawn with the permission of Ref. [61]. Copyright 2015 The American Chemical Society).

Z-schema is the other kind of T-2 type heterojunction, where the work function of component $B$ is less than that of A, as shown in Figure 10c. When they contact and form a heterojunction, the electrons flow from $\mathrm{B}$ to $\mathrm{A}$ and build an electric field towards $\mathrm{A}$ at the interface. Under light irradiation, the photogenerated electrons at the CB of A will flow to the VB of $B$ through the space electric field at the interface, and maintain the highly redox-active electrons and holes at the $\mathrm{CB}$ of $\mathrm{B}$ and $\mathrm{VB}$ of $\mathrm{A}$, respectively. The Z-type heterojunction provides a better solution for improving the charge separation efficiency and redox ability [112-114]. In recent years, direct and indirect Z-type photocatalysts have been developed, including $\mathrm{LaFeO}_{3} / \mathrm{SnS}_{2}$ [126], $\mathrm{InVO}_{4} / \mathrm{AgVO}_{3}$ [89], g- $\mathrm{C}_{3} \mathrm{~N}_{4} / \mathrm{MnO}_{2}$ [127], and $\mathrm{ZnO} / \mathrm{CdS}$ [128]. However, few studies have examined the construction of the Z-type heterojunction in electrospun ceramic fibers. Because the electrospun ceramic fibers possess better flexibility, are easily recycled and environmentally friendly, have rich surface active sites, and are low cost, it is expected that the electrospun Z-type ceramic nanofibers will show good photocatalytic performance, and is a promising future direction.

\subsection{Defective Surfaces}

Surface defect engineering has been found to be the critical factor to improve photocatalytic activity, and can trap the photogenerated electrons or holes and modify the phonon transport [129-131]. Taking advantage of doping and atmosphere heat treatment, different kinds of defects can be controllably introduced into electrospun ceramic fibers. For example, Cheng et al. introduced oxygen vacancy defects at the surface of electrospun $(\mathrm{ZnO})_{x}(\mathrm{GaN})_{1-x}$ nanofibers through atmosphere sintering and investigated their photocatalytic performance and mechanism [56]. The change in the concentration of $\mathrm{RhB}$ as a function of time is plotted in Figure 14a, which shows that the optimal nitridation temperature is $850^{\circ} \mathrm{C}$. After $100 \mathrm{~min}$ visible light irradiation, the RhB is almost completely 
degraded by the $(\mathrm{ZnO})_{\times}(\mathrm{GaN})_{1-\mathrm{x}}$ nanofibers and becomes colorless (Figure 14b). By dynamic calculation, the nanofibers calcined at $850{ }^{\circ} \mathrm{C}$ exhibit the highest rate constant $k$ of $0.058 \mathrm{~min}^{-1}$ and apparent quantum efficiency (AQE) of $29.4 \%$, which is about 40 times greater than that of the nanowires calcined at $600{ }^{\circ} \mathrm{C}$ (Figure 14c). Moreover, the electrospun $(\mathrm{ZnO})_{\mathrm{x}}(\mathrm{GaN})_{1-\mathrm{x}}$ nanofibers show very good stability in the cyclic test (Figure $14 \mathrm{~d}$ ). The authors confirmed the formation of oxygen and gallium vacancy, and proposed that the surface oxygen vacancy can trap photogenerated electrons and delay the recombination of the photogenerated electron-hole pairs, therefore enhancing the performance of the electrospun $(\mathrm{ZnO})_{\mathrm{x}}(\mathrm{GaN})_{1-\mathrm{x}}$ nanofibers, as shown in Figure 14e.
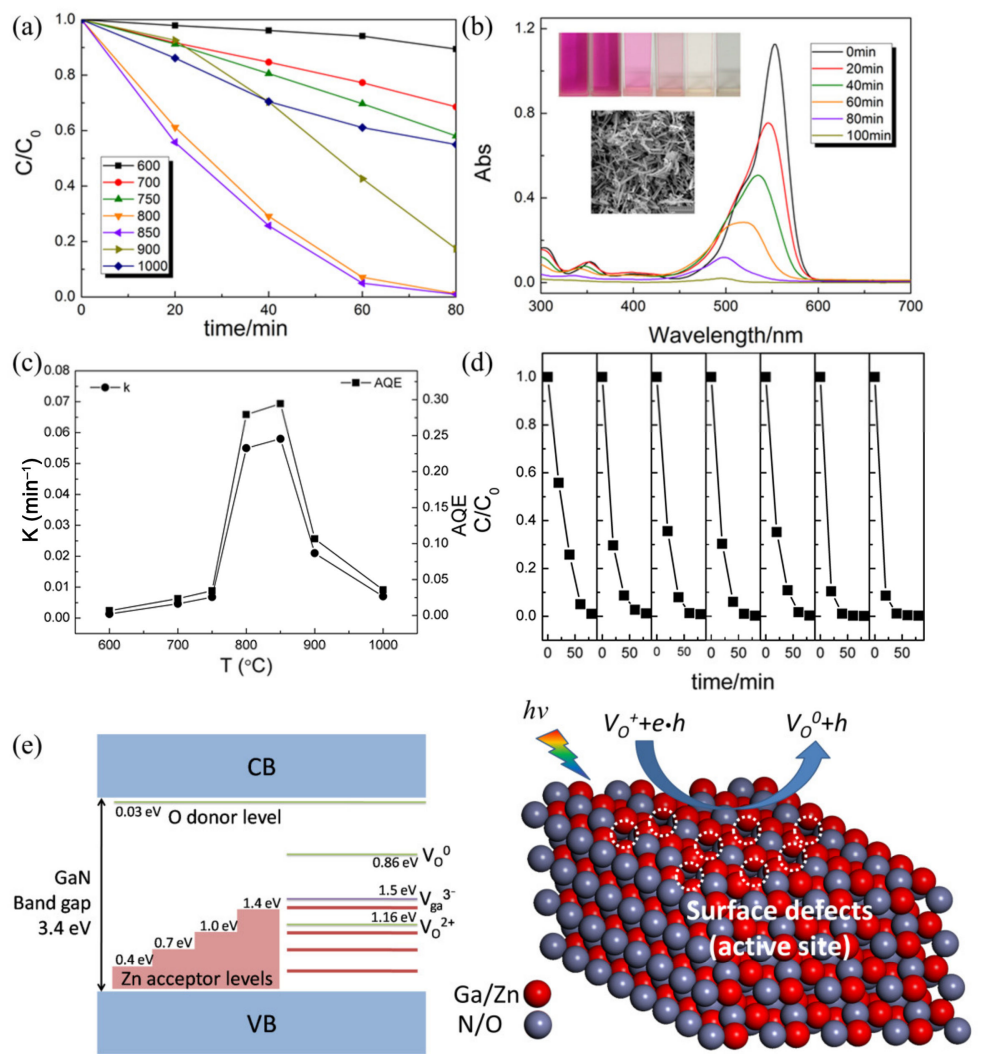

Figure 14. (a) Photodegradation of RhB by zinc-doped gallium oxynitride nanowires calcined at different temperatures; (b) the absorption spectrum of the RhB solution in the presence of the nanowires. The inset illustrates photos for the RhB solutions photodegraded for different times and the SEM image of the specimen reclaimed after photocatalytic measurement; (c) degradation rate constants and apparent quantum efficiencies for the nanowires; $(d)$ the repeatability tests of the specimen calcined at $850^{\circ} \mathrm{C}$; (e) schematic illustrations of the surface defect-related photocatalytic mechanism for zinc-doped gallium oxynitride nanowires. (Redrawn with the permission of Ref. [56]. Copyright 2017 Elsevier ).

Wang et al. prepared $\mathrm{Mn}^{2+}$-doped and $\mathrm{N}$-decorated $\mathrm{ZnO}$ nanofibers (NFs) enriched with oxygen vacancy defects by electrospinning [54]. To introduce a high density of oxygen vacancies and nitrogen, the precursor fibers were annealed under an atmosphere mixture of $50 \%$ air and $50 \%$ nitrogen at the beginning, and full nitrogen after heating to the temperature of $550{ }^{\circ} \mathrm{C}$. The as-prepared fiber catalyst exhibited excellent visible-light photocatalytic activity and an apparent quantum efficiency up to $12.77 \%$, which is 50 times higher than that of pure $\mathrm{ZnO}$, as shown in Figure 16a,b. Through comprehensive structural characterization and calculation, they proposed that the oxygen vacancy formed mid-gap states, which serve as intermediate steps for the photoexcitation process. Moreover, these vacancy defects can capture electrons from the $\mathrm{CB}$ and form a neutral state $\left(\mathrm{V}_{\mathrm{O}}{ }^{*}\right)$, helping the holes release from the catalysts, and consequently delaying the recombination process 
(Figure 16c). Thus, the photocatalytic performance of the $\mathrm{Mn}^{2+}$-doped and $\mathrm{N}$-decorated $\mathrm{ZnO}$ nanofibers was enhanced dramatically. Therefore, the introduction of defects can not only tune the band gap, but also prevent the recombination of photogenerated electrons and holes, providing an ideal solution to enhance the activity of ceramic fiber photocatalysts. However, the location, content, and state of defects are not easily controlled and characterized. These issues not only exist in photocatalytic materials prepared by electrospinning, and deserve further in-depth investigation.
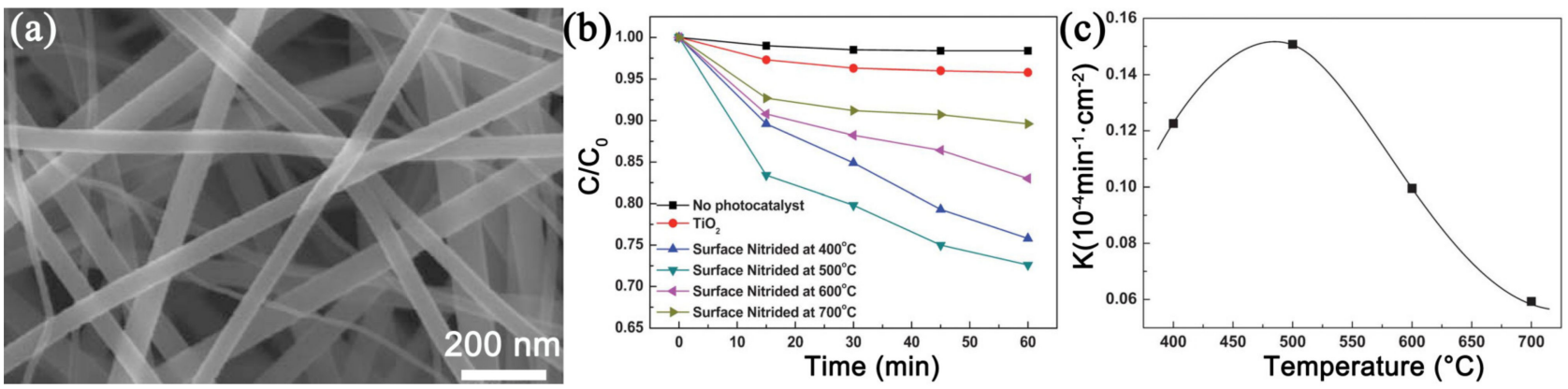

Figure 15. Morphology of $\mathrm{N}-\mathrm{TiO}_{2}$ nanofibers nitrided under $\mathrm{NH}_{3}$ flow at $400{ }^{\circ} \mathrm{C}$ for $4 \mathrm{~h}$ (a); visible-light photocatalytic activity of $\mathrm{N}_{-} \mathrm{TiO}_{2}$ with different nitride temperatures (b); the relationship between the reaction rate constant and the nitride temperature (c). (Redrawn with the permission of Ref. [55]. Copyright 2012 The Royal Society of Chemistry).
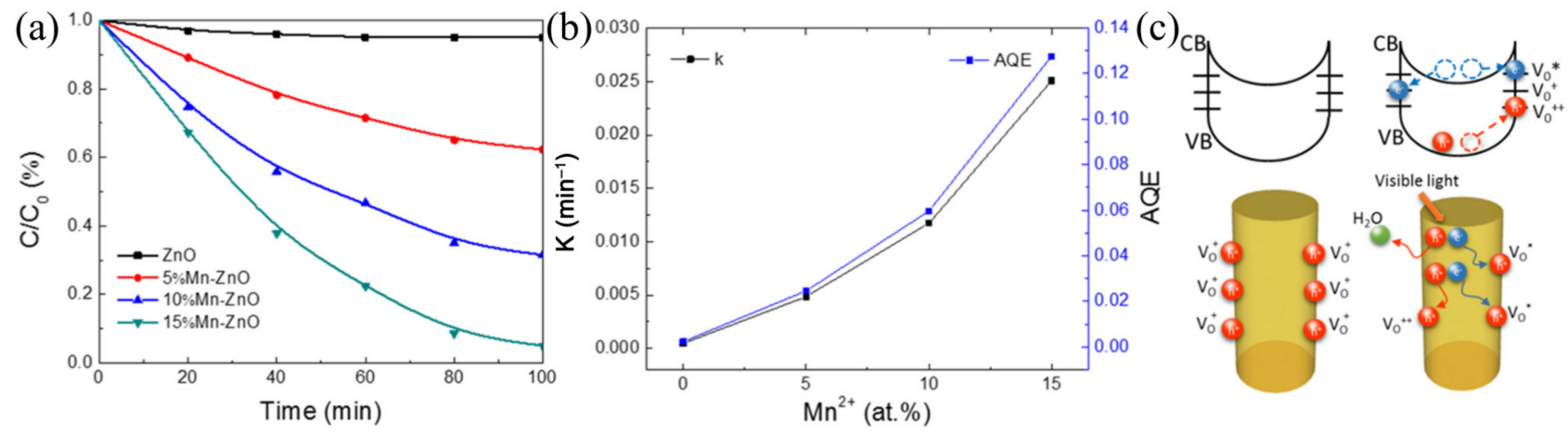

Figure 16. (a) Photodegradation of $\mathrm{RhB}$ by $\mathrm{ZnO}$ nanofibers doped with different $\mathrm{Mn}^{2+}$ concentrations. (b) Degradation rate constants and apparent quantum efficiencies. (c) Schematic of trapping and photocatalytic mechanism in a single NF under dark and visible light. (Redrawn with the permission of Ref. [54]. Copyright 2016 Wang, Y. et al.).

\section{Conclusions}

Electrospun ceramic nanofibers have been extensively studied as photocatalysts for pollutant degradation and water splitting during the past decade. In this review, we summarized the typical ceramic nanofiber catalysts and recent progress for improving their performance, including: (1) the fundamental principles and bottlenecks of the photocatalysis process; (2) UV and visible-light-response ceramic fiber photocatalysts prepared by electrospinning; (3) the strategies used to expand the light absorption range of ceramic fiber photocatalysts; and (4) various types of heterostructure used for efficient carrier separation. At present, electrospun ceramic nanofibers with adjustable band structure have great application potential in the field of photocatalysis, and the electrospinning technique offers a scalable, easy, and low-cost route to produce ceramic fiber photocatalysts. Due to the efforts of many research groups, electrospinning has been developed as a technique capable of producing a variety of ceramics and composite fibers with fine structure and controllable morphology.

In the future, the photocatalytic efficiency and quantum yield of ceramic fiber photocatalysts should be enhanced for practical solar engineering. It is expected that novel strategies for improved light-harvesting and carrier separation will be realized in electro- 
spun ceramic fibers. Moreover, the development of directly electrospun ceramic fabric or a mat with high solar energy conversion efficiency will become important, especially for the application to water splitting and hydrogen production. Regarding electrospinning technology, mass production of functional fibers with designed and controllable morphology will be one of the leading development directions. Then, combining the electrospinning techniques with other well-developed techniques for materials processing can increase the diversity of material and structure types, and open provide access to new properties and applications. As a result of the rapid innovation of science and technology, electrospinning will surely become an effective method for making 1D nanomaterials with a fine structure and ideal performance that is not limited to the field of photocatalysis.

Author Contributions: Conceptualization, W.P. and Y.X.; investigation and resources, J.C., H.L., D.L., Y.W., and H.W.; writing—original draft preparation, Y.X.; writing—review and editing, Y.X. and W.P.; supervision, W.P.; project administration, W.P.; funding acquisition, W.P. All authors have read and agreed to the published version of the manuscript.

Funding: The National Natural Science Foundation of China (Nos. 51323001, 51802173, 50872063 and 52102068).

Conflicts of Interest: The authors declare no competing interest.

\section{References}

1. Greiner, A.; Wendorff, J.H. Electrospinning: A fascinating method for the preparation of ultrathin fibers. Angew. Chem. 2010, 46, 5670-5703. [CrossRef]

2. Pan, W.; Wu, H.; Lin, D.; Li, H.; Zhang, W. Electrospinning of nanofibers for photocatalyst. Curr. Org. Chem. 2013, 17, 1371-1381. [CrossRef]

3. Li, D.; Xia, Y. Electrospinning of nanofibers: Reinventing the Wheel? Adv. Mater. 2004, 16, 1151-1170. [CrossRef]

4. Cooley, J.F. Apparatus for Electrically Dispersing Fluids. U.S. Patent US692,631, 1902.

5. Dan, L.; Zhu, M.; Jiang, Z.; Jiang, S.; Huang, C. Green electrospun nanofibers and their application in air filtration. Macromol. Mater. Eng. 2018, 303, 1800336.

6. Wu, H.; Lin, D.; Pan, W. Fabrication, assembly, and electrical characterization of CuO nanofibers. Appl. Phys. Lett. 2006, 89, 133125. [CrossRef]

7. Wu, H.; Sun, Y.; Lin, D.; Zhang, R.; Zhang, C.; Pan, W. GaN nanofibers based on electrospinning: Facile synthesis, controlled assembly, precise doping, and application as high performance UV photodetector. Adv. Mater. 2009, 21, 227-231. [CrossRef]

8. Xing, Y.; Dan, W.; Fan, Y.; Li, X.A. Low temperature synthesis of high-entropy $\left(\mathrm{Y}_{0.2} \mathrm{Yb}_{0.2} \mathrm{Sm}_{0.2} \mathrm{Eu}_{0.2} \mathrm{Er}_{0.2}\right)_{2} \mathrm{O}_{3}$ nanofibers by a novel electrospinning method. J. Mater. Sci. Technol. 2022, 103, 215-220. [CrossRef]

9. Zhang, D.; Li, J.; Su, Z.; Hu, S.; Li, H.; Yan, Y. Electrospun polyporous VN nanofibers for symmetric all-solid-state supercapacitors. J. Adv. Ceram. 2018, 7, 246-255. [CrossRef]

10. Lin, D.; Pan, W.; Wu, H. Morphological control of centimeter long aluminum-doped zinc oxide nanofibers prepared by electrospinning. J. Am. Ceram. Soc. 2007, 90,71-76. [CrossRef]

11. Lin, D.; Wu, H.; Zhang, R.; Pan, W. Preparation of ZnS Nanofibers Via Electrospinning. J. Am. Ceram. Soc. 2007, 90, 3664-3666. [CrossRef]

12. Wu, H.; Pan, W. Preparation of Zinc Oxide Nanofibers by Electrospinning. J. Am. Ceram. Soc. 2006, 89, 699-701. [CrossRef]

13. Li, H.; Pan, W.; Zhang, W.; Huang, S.; Wu, H. TiN nanofibers: A new material with high conductivity and transmittance for transparent conductive electrodes. Adv. Funct. Mater. 2013, 23, 209-214. [CrossRef]

14. Xing, Y.; Cheng, J.; Zhang, M.; Zhao, M.; Ye, L.; Pan, W. A novel inorganic Ni-La ${ }_{2} \mathrm{O}_{3}$ composite with superfast and versatile water purification behavior. ACS Appl. Mater. Inter. 2018, 10, 43723-43729. [CrossRef]

15. Hong, J.; Yeo, M.; Yang, G.H.; Kim, G. Cell-electrospinning and its application for tissue engineering. Int. J. Mol. Sci. 2019, 20, 6208. [CrossRef]

16. Wang, Y.; Cheng, J.; Xing, Y.; Shahid, M.; Nishijima, H.; Pan, W. Stretchable platinum network-based transparent electrodes for highly sensitive wearable electronics. Small 2017, 13, 1604291. [CrossRef] [PubMed]

17. Lin, D.; Wu, H.; Zhang, R.; Pan, W. Enhanced photocatalysis of electrospun Ag-ZnO heterostructured nanofibers. Chem. Mater. 2009, 21, 3479-3484. [CrossRef]

18. Hisatomi, T.; Kubota, J.; Domen, K. Recent advances in semiconductors for photocatalytic and photoelectrochemical water splitting. Chem. Soc. Rev. 2014, 43, 7520-7535. [CrossRef] [PubMed]

19. Lewis, N.S. Toward cost-effective solar energy use. Science 2007, 315, 798-801. [CrossRef] [PubMed]

20. Lee, K.M.; Lai, C.W.; Ngai, K.S.; Juan, J.C. Recent developments of zinc oxide based photocatalyst in water treatment technology: A review. Water Res. 2016, 88, 428-448. [CrossRef] [PubMed] 
21. Liu, J.; Liu, Y.; Liu, N.; Han, Y.; Zhang, X.; Huang, H.; Lifshitz, Y.; Lee, S.T.; Zhong, J.; Kang, Z. Metal-free efficient photocatalyst for stable visible water splitting via a two-electron pathway. Science 2015, 347, 970-974. [CrossRef] [PubMed]

22. Chong, M.N.; Jin, B.; Chow, C.W.; Saint, C. Recent developments in photocatalytic water treatment technology: A review. Water Res. 2010, 44, 2997-3027. [CrossRef]

23. Fujishima, A.; Honda, K. Electrochemical photolysis of water at a semiconductor electrode. Nature 1972, 238, 37-38. [CrossRef] [PubMed]

24. Xiang, Q.; Yu, J.; Jaroniec, M. Graphene-based semiconductor photocatalysts. Chem. Soc. Rev. 2012, 41, 782-796. [CrossRef] [PubMed]

25. Li, X.; Yu, J.; Low, J.; Fang, Y.; Xiao, J.; Chen, X. Engineering heterogeneous semiconductors for solar water splitting. J. Mater. Chem. A 2015, 3, 2485-2534. [CrossRef]

26. Hoffmann, M.R.; Martin, S.T.; Choi, W.; Bahnemann, D.W. Environmental applications of semiconductor photocatalysis. Chem. Rev. 1995, 95, 69-96. [CrossRef]

27. Kudo, A.; Miseki, Y. Heterogeneous photocatalyst materials for water splitting. Chem. Soc. Rev. 2009, 38, 253-278. [CrossRef]

28. Aldana, J.; Wang, Y.A.; Peng, X. Photochemical instability of CdSe nanocrystals coated by hydrophilic thiols. J. Am. Chem. Soc. 2001, 123, 8844-8850. [CrossRef]

29. Fujishima, A.; Zhang, X.; Tryk, D.A. $\mathrm{TiO}_{2}$ photocatalysis and related surface phenomena. Surf. Sci. Rep. 2008, 63, 515-582. [CrossRef]

30. Rohj, R.K.; Hossain, A.; Mahadevan, P.; Sarma, D.D. Band gap reduction in ferroelectric $\mathrm{BaTiO}_{3}$ through heterovalent Cu-Te co-doping for visible-light photocatalysis. Front. Chem. 2021, 9, 682979. [CrossRef] [PubMed]

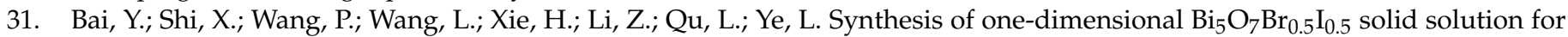
effective real oilfield wastewater treatment via exciton photocatalytic process. J. Taiwan Inst. Chem. E 2018, 91, 358-368. [CrossRef]

32. Liu, M.; Jin, X.; Li, S.; Billeau, J.B.; Peng, T.; Li, H.; Zhao, L.; Zhang, Z.; Claverie, J.P.; Razzari, L.; et al. Enhancement of Scattering and Near Field of $\mathrm{TiO}_{2}$-Au Nanohybrids Using a Silver Resonator for Efficient Plasmonic Photocatalysis. ACS Appl. Mater. Inter. 2021, 13, 34714-34723. [CrossRef] [PubMed]

33. Borges, M.; Sierra, M.; Mendez-Ramos, J.; Acosta-Mora, P.; Ruiz-Morales, J.; Esparza, P. Solar degradation of contaminants in water: $\mathrm{TiO}_{2}$ solar photocatalysis assisted by up-conversion luminescent materials. Sol. Energy Mater. Sol. Cells 2016, 155, 194-201. [CrossRef]

34. Emeline, A.V.; Rudakova, A.V.; Mikhaylov, R.V.; Bulanin, K.M.; Bahnemann, D.W. Photoactive heterostructures: How they are made and explored. Catalysts 2021, 11, 294. [CrossRef]

35. Zhou, W.; Fu, H.G. Defect-mediated electron-hole separation in semiconductor photocatalysis. Inorg. Chem. Front. 2018, 5, 1240-1254. [CrossRef]

36. Bai, S.; Zhang, N.; Gao, C.; Xiong, Y. Defect engineering in photocatalytic materials. Nano Energy 2018, 53, 296-336. [CrossRef]

37. Bi, Y.; Ouyang, S.; Umezawa, N.; Cao, J.; Ye, J. Facet Effect of Single-Crystalline $\mathrm{Ag}_{3} \mathrm{PO}_{4}$ Sub-Microcrystals on Photocatalytic Properties. J. Am. Chem. Soc. 2011, 133, 6490-6492. [CrossRef] [PubMed]

38. Chen, F.; Huang, H.; Guo, L.; Zhang, Y.; Ma, T. The Role of Polarization in Photocatalysis. Angew. Chem. 2019, 58, 10061-10073. [CrossRef]

39. Lin, D.; Wu, H.; Zhang, R.; Zhang, W.; Pan, W. Facile Synthesis of Heterostructured ZnO-ZnS Nanocables and Enhanced Photocatalytic Activity. J. Am. Ceram. Soc. 2010, 93, 3384-3389. [CrossRef]

40. Cheng, J.; Wang, Y.; Xing, Y.; Shahid, M.; Pan, W. A stable and highly efficient visible-light photocatalyst of $\mathrm{TiO}_{2}$ and heterogeneous carbon core-shell nanofibers. RSC Adv. 2017, 7, 15330-15336. [CrossRef]

41. Linsebigler, A.L.; Lu, G.; John, T.; Yates, J. Photocatalysis on $\mathrm{TiO}_{\mathrm{n}}$ Surfaces: Principles, Mechanisms, and Selected Results. Chem. Rev. 1995, 95, 735-758. [CrossRef]

42. Moniz, S.J.A.; Shevlin, S.A.; Martin, D.J.; Guo, Z.; Tang, J. Visible-light driven heterojunction photocatalysts for water splitting-A critical review. Energ. Environ. Sci. 2015, 8, 731-759. [CrossRef]

43. Guo, Q.; Zhou, C.; Ma, Z.; Yang, X. Fundamentals of $\mathrm{TiO}_{2}$ Photocatalysis: Concepts, Mechanisms, and Challenges. Adv. Mater. 2019, 31, e1901997. [CrossRef] [PubMed]

44. Tong, H.; Ouyang, S.; Bi, Y.; Umezawa, N.; Oshikiri, M.; Ye, J. Nano-photocatalytic materials: Possibilities and challenges. Adv. Mater. 2012, 24, 229-251. [CrossRef]

45. Wang, Z.; Li, C.; Domen, K. Recent developments in heterogeneous photocatalysts for solar-driven overall water splitting. Chem. Soc. Rev. 2019, 48, 2109-2125. [CrossRef]

46. Wu, H.; Pan, W.; Lin, D.; Li, H. Electrospinning of ceramic nanofibers: Fabrication, assembly and applications. J. Adv. Ceram. 2012, 1, 2-23. [CrossRef]

47. Wu, H.; Lin, D.; Pan, W. High Performance Surface-Enhanced Raman Scattering Substrate Combining Low Dimensional and Hierarchical Nanostructures. Langmuir 2010, 26, 6865-6868. [CrossRef] [PubMed]

48. Li, H.; Zhang, W.; Li, B.; Pan, W. Diameter-Dependent Photocatalytic Activity of Electrospun TiO 2 Nanofiber. J. Am. Ceram. Soc. 2010, 93, 2503-2506. [CrossRef]

49. Yi, S.; Sun, S.; Zhang, Y.; Zou, Y.; Dai, F.; Si, Y. Scalable fabrication of bimetal modified polyacrylonitrile (PAN) nanofibrous membranes for photocatalytic degradation of dyes. J. Colloid Interface Sci. 2020, 559, 134-142. [CrossRef] [PubMed] 
50. Chen, G.; Wang, Y.; Fan, L.; Xiong, X.; Zhu, C.; Wu, C.; Dai, G. Electrospun $\mathrm{CuWO}_{4}$ nanofibers for visible light photocatalysis. Mater. Lett. 2019, 251, 23-25. [CrossRef]

51. Lv, C.; Sun, J.; Chen, G.; Zhou, Y.; Li, D.; Wang, Z.; Zhao, B. Organic salt induced electrospinning gradient effect: Achievement of $\mathrm{BiVO}_{4}$ nanotubes with promoted photocatalytic performance. Appl. Catal. B Environ. 2017, 208, 14-21. [CrossRef]

52. Pantò, F.; Dahrouch, Z.; Saha, A.; Patanè, S.; Santangelo, S.; Triolo, C. Photocatalytic degradation of methylene blue dye by porous zinc oxide nanofibers prepared via electrospinning: When defects become merits. Appl. Surf. Sci. 2021, 557, 149830. [CrossRef]

53. Wang, Y.; Hao, X.; Wang, Z.; Dong, M.; Cui, L. Facile fabrication of $\mathrm{Mn}^{2+}$-doped ZnO photocatalysts by electrospinning. R. Soc. Open Sci. 2020, 7, 191050. [CrossRef]

54. Wang, Y.; Cheng, J.; Yu, S.; Alcocer, E.J.; Shahid, M.; Wang, Z.; Pan, W. Synergistic effect of N-decorated and Mn ${ }^{2+}$ doped ZnO nanofibers with enhanced photocatalytic activity. Sci. Rep. 2016, 6, 32711. [CrossRef] [PubMed]

55. Li, H.; Zhang, W.; Huang, S.; Pan, W. Enhanced visible-light-driven photocatalysis of surface nitrided electrospun TiO ${ }_{2}$ nanofibers. Nanoscale 2012, 4, 801-806. [CrossRef] [PubMed]

56. Cheng, J.; Wang, Y.; Xing, Y.; Shahid, M.; Pan, W. Surface defects decorated zinc doped gallium oxynitride nanowires with high photocatalytic activity. Appl. Catal. B Environ. 2017, 209, 53-61. [CrossRef]

57. Zhang, R.; Wu, H.; Lin, D.; Pan, W. Photocatalytic and Magnetic Properties of the $\mathrm{Fe}-\mathrm{TiO}_{2} / \mathrm{SnO}_{2}$ Nanofiber Via Electrospinning. J. Am. Ceram. Soc. 2010, 93, 605-608. [CrossRef]

58. Duan, Z.; Huang, Y.; Zhang, D.; Chen, S. Electrospinning fabricating $\mathrm{Au} / \mathrm{TiO}_{2}$ network-like nanofibers as visible light activated Photocatalyst. Sci. Rep. 2019, 9, 8008. [CrossRef]

59. Saha, D.; Gismondi, P.; Kolasinski, K.W.; Shumlas, S.L.; Rangan, S.; Eslami, B.; McConnell, A.; Bui, T.; Cunfer, K. Fabrication of electrospun nanofiber composite of $\mathrm{g}-\mathrm{C}_{3} \mathrm{~N}_{4}$ and Au nanoparticles as plasmonic photocatalyst. Surf. Interfaces 2021, $26,101367$. [CrossRef]

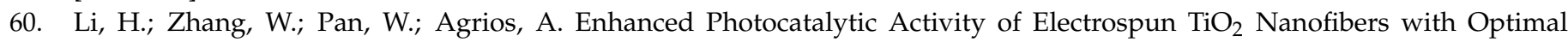
Anatase/Rutile Ratio. J. Am. Ceram. Soc. 2011, 94, 3184-3187. [CrossRef]

61. Cheng, J.; Feng, J.; Pan, W. Enhanced photocatalytic activity in electrospun bismuth vanadate nanofibers with phase junction. ACS Appl. Mater. Inter. 2015, 7, 9638-9644. [CrossRef]

62. Liu, H.; Zhang, Z.G.; He, H.W.; Wang, X.X.; Zhang, J.; Zhang, Q.Q.; Tong, Y.F.; Liu, H.L.; Ramakrishna, S.; Yan, S.Y.; et al. One-Step Synthesis Heterostructured g- $\mathrm{C}_{3} \mathrm{~N}_{4} / \mathrm{TiO}_{2}$ Composite for Rapid Degradation of Pollutants in Utilizing Visible Light. Nanomaterials 2018, 8, 842. [CrossRef] [PubMed]

63. Pant, B.; Ojha, G.P.; Kuk, Y.S.; Kwon, O.H.; Park, Y.W.; Park, M. Synthesis and Characterization of $\mathrm{ZnO}-\mathrm{TiO}_{2} /$ Carbon Fiber Composite with Enhanced Photocatalytic Properties. Nanomaterials 2020, 10, 1960. [CrossRef]

64. Cheng, J.; Wang, Y.; Xing, Y.; Muhammad, S.; Pan, W. Synthesis and Photocatalytic Performance of $\mathrm{Ag} / \mathrm{BiVO}_{4} \mathrm{Composite}$ Nanofiber. Rare Metal Mat. Eng. 2018, 47, 356-360.

65. Zhang, R.; Wu, H.; Lin, D.; Pan, W. Preparation of Necklace-Structured $\mathrm{TiO}_{2} / \mathrm{SnO}_{2}$ Hybrid Nanofibers and Their Photocatalytic Activity. J. Am. Ceram. Soc. 2009, 92, 2463-2466. [CrossRef]

66. Pant, B.; Prasad Ojha, G.; Acharya, J.; Park, M. Ag $\mathrm{AO}_{4}-\mathrm{TiO}_{2}$-Carbon nanofiber Composite: An efficient Visible-light photocatalyst obtained from eelectrospinning and hydrothermal methods. Sep. Purif. Technol. 2021, 276, 119400. [CrossRef]

67. Pant, B.; Barakat, N.A.M.; Pant, H.R.; Park, M.; Saud, P.S.; Kim, J.W.; Kim, H.Y. Synthesis and photocatalytic activities of CdS/TiO 2 nanoparticles supported on carbon nanofibers for high efficient adsorption and simultaneous decomposition of organic dyes. $J$. Colloid Interface Sci. 2014, 434, 159-166. [CrossRef] [PubMed]

68. Zhang, L.; Shen, Q.; Zheng, S.; Yu, L.; Huang, F.; Zhang, C.; Sheng, J.; Yang, H. Direct electrospinning preparation of Z-scheme mixed-crystal $\mathrm{Bi}_{2} \mathrm{O}_{3} / g-\mathrm{C}_{3} \mathrm{~N}_{4}$ composite photocatalysts with enhanced visible-light photocatalytic activity. New J. Chem. 2021, 45 , 14522-14531. [CrossRef]

69. Panthi, G.; Kwon, O.H.; Kuk, Y.S.; Gyawali, K.R.; Park, Y.W.; Park, M. Ternary Composite of Co-Doped CdSe@electrospun Carbon Nanofibers: A Novel Reusable Visible Light-Driven Photocatalyst with Enhanced Performance. Catalysts 2020, 10, 348. [CrossRef]

70. Li, X.; Chen, D.; Li, N.; Xu, Q.; Li, H.; He, J.; Lu, J. Hollow $\mathrm{SnO}_{2}$ nanotubes decorated with $\mathrm{ZnIn}_{2} \mathrm{~S}_{4}$ nanosheets for enhanced visible-light photocatalytic activity. J. Alloys Compd. 2020, 843, 155772. [CrossRef]

71. Li, X.; Raza, S.; Liu, C. Directly electrospinning synthesized Z-scheme heterojunction $\mathrm{TiO}_{2} @ \mathrm{Ag}_{\mathrm{O}} \mathrm{Cu}_{2} \mathrm{O}$ nanofibers with enhanced photocatalytic degradation activity under solar light irradiation. J. Environ. Chem. Eng. 2021, 9, 106133. [CrossRef]

72. Sabzehmeidani, M.M.; Karimi, H.; Ghaedi, M.; Avargani, V.M. Construction of efficient and stable ternary $\mathrm{ZnFe} 2 \mathrm{O}_{4} / \mathrm{Ag} / \mathrm{AgBr}$ Z-scheme photocatalyst based on $\mathrm{ZnFe}_{2} \mathrm{O}_{4}$ nanofibers under LED visible light. Mater. Res. Bull. 2021, 143, 111449. [CrossRef]

73. Kessick, R.; Fenn, J.; Tepper, G. The use of AC potentials in electrospraying and electrospinning processes. Polymer 2004, 45, 2981-2984. [CrossRef]

74. Reneker, D.H.; Chun, I. Nanometre diameter fibres of polymer, produced by electrospinning. Nanotechnology 1996, 7, $216-223$. [CrossRef]

75. Reneker, D.H.; Yarin, A.L.; Fong, H.; Koombhongse, S. Bending instability of electrically charged liquid jets of polymer solutions in electrospinning. J. Appl. Phys. 2000, 87, 4531-4547. [CrossRef]

76. Shin, Y.M.; Hohman, M.M.; Brenner, M.P.; Rutledge, G.C. Electrospinning: A whipping fluid jet generates submicron polymer fibers. Appl. Phys. Lett. 2001, 78, 1149-1151. [CrossRef] 
77. Yarin, A.L.; Koombhongse, S.; Reneker, D.H. Taylor cone and jetting from liquid droplets in electrospinning of nanofibers. J. Appl. Phys. 2001, 90, 4836-4846. [CrossRef]

78. Shina, Y.M.; Hohmanb, M.M.; Brennerc, M.P.; Rutledge, G.C. Experimental characterization of electrospinning: The electrically forced jet and instabilities. Polymer 2001, 42, 9955-9967. [CrossRef]

79. Fridrikh, S.V.; Yu, J.H.; Brenner, M.P.; Rutledge, G.C. Controlling the fiber diameter during electrospinning. Phys. Rev. Lett. 2003, 90, 144502. [CrossRef]

80. Feng, J.J. The stretching of an electrified non-Newtonian jet: A model for electrospinning. Phys. Fluids 2002, 14, 3912-3926. [CrossRef]

81. Ren, Y.; Dong, Y.; Feng, Y.; Xu, J. Compositing Two-Dimensional Materials with $\mathrm{TiO}_{2}$ for Photocatalysis. Catalysts 2018, 8 , 590. [CrossRef]

82. Marinho, B.A.; de Souza, S.M.A.G.U.; de Souza, A.A.U.; Hotza, D. Electrospun $\mathrm{TiO}_{2}$ nanofibers for water and wastewater treatment: A review. J. Mater. Sci. 2020, 56, 5428-5448. [CrossRef]

83. Dudley, B. BP Statistical Review of World Energy; BP: London, UK, 2013.

84. Yang, W.; Chen, Y.; Gao, S.; Sang, L.; Tao, R.; Sun, C.; Shang, J.K.; Li, Q. Post-illumination activity of $\mathrm{Bi}_{2} \mathrm{WO}_{6}$ in the dark from the photocatalytic "memory" effect. J. Adv. Ceram. 2021, 10, 355-367. [CrossRef]

85. Gao, B.; Hu, D.; Xiao, C.; Li, D.; Zheng, Y. Enhanced visible-light-driven photocatalytic performance of $\mathrm{AgNbO}_{3}$ cubes with a high-energy (001) facet. J. Phys. Chem. Solids 2019, 135, 109083. [CrossRef]

86. Wu, J.; Li, X.; Min, X.; Xing, Y. A novel 2D graphene oxide modified $\alpha-\mathrm{AgVO}_{3}$ nanorods: Design, fabrication and enhanced visible-light photocatalytic performance. J. Adv. Ceram. 2021. [CrossRef]

87. Jing, L.; Xu, Y.; Huang, S.; Xie, M.; He, M.; Xu, H.; Li, H.; Zhang, Q. Novel magnetic CoFe $\mathrm{O}_{4} / \mathrm{Ag} / \mathrm{Ag}_{3} \mathrm{VO}_{4}$ composites: Highly efficient visible light photocatalytic and antibacterial activity. Appl. Catal. B Environ. 2016, 199, 11-22. [CrossRef]

88. Sajid, M.M.; Shad, N.A.; Javed, Y.; Khan, S.B.; Zhai, H. Preparation and characterization of Vanadium pentoxide $\left(\mathrm{V}_{2} \mathrm{O}_{5}\right)$ for photocatalytic degradation of monoazo and diazo dyes. Sur. Interfaces 2020, 19, 100502. [CrossRef]

89. Zhang, X.; Zhang, J.; Yu, J.; Zhang, Y.; Cui, Z.; Sun, Y.; Hou, B. Fabrication of $\mathrm{InVO}_{4} / \mathrm{AgVO}_{3}$ heterojunctions with enhanced photocatalytic antifouling efficiency under visible-light. Appl. Catal. B Environ. 2018, 220, 57-66. [CrossRef]

90. Shang, M.; Wang, W.; Ren, J.; Sun, S.; Wang, L.; Zhang, L. A practical visible-light-driven $\mathrm{Bi}_{2} \mathrm{WO}_{6}$ nanofibrous mat prepared by electrospinning. J. Mater. Chem. 2009, 19, 6213. [CrossRef]

91. Sedghi, R.; Moazzami, H.R.; Hosseiny Davarani, S.S.; Nabid, M.R.; Keshtkar, A.R. A one step electrospinning process for the preparation of polyaniline modified $\mathrm{TiO}_{2}$ / polyacrylonitile nanocomposite with enhanced photocatalytic activity. J. Alloys Compd. 2017, 695, 1073-1079. [CrossRef]

92. Chen, X.; Liu, L.; Yu, P.; Mao, S. Increasing Solar Absorption for Photocatalysis with Black Hydrogenated Titanium Dioxide Nanocrystals. Science 2011, 331, 746-750. [CrossRef] [PubMed]

93. Sadeghzadeh-Attar, A. Photocatalytic degradation evaluation of $\mathrm{N}$-Fe codoped aligned $\mathrm{TiO}_{2}$ nanorods based on the effect of annealing temperature. J. Adv. Ceram. 2020, 9, 107-122. [CrossRef]

94. Xu, H.M.; Wang, H.C.; Shen, Y.; Lin, Y.H.; Nan, C.W. Low-dimensional nanostructured photocatalysts. J. Adv. Ceram. 2015, 4, 159-182. [CrossRef]

95. Wu, Q.; Chai, S.; Yang, H.; Gao, Z.; Zhang, R.; Wang, L.; Kang, L. Enhancing visible-light driven photocatalytic performance of $\mathrm{BiOBr}$ by self-doping and in-situ deposition strategy: A synergistic effect between $\mathrm{Bi}^{5+}$ and metallic Bi. Sep. Purif. Technol. 2020, 253, 117388. [CrossRef]

96. Chen, X.; Shen, S.; Guo, L.; Mao, S.S. Semiconductor-based photocatalytic hydrogen generation. Chem. Rev. 2010, 110, 6503-6570. [CrossRef] [PubMed]

97. Borgarello, E.; Kiwi, J.; Graetzel, M.; Pelizzetti, E.; Visca, M. Visible light induced water cleavage in colloidal solutions of chromium-doped titanium dioxide particles. J. Am. Chem. Soc. 1982, 104, 2996-3002. [CrossRef]

98. Jing, P.; Wei, L.; Su, Q.; Xie, E. High photocatalytic activity of V-doped $\mathrm{SrTiO}_{3}$ porous nanofibers produced from a combined electrospinning and thermal diffusion process. Beilstein J. Nanotechnol. 2015, 6, 1281-1286. [CrossRef] [PubMed]

99. Jouypazadeh, H.; Farrokhpour, H.; Momeni, M.M. Theoretical Investigation of the water splitting photocatalytic properties of pristine, $\mathrm{Nb}$ and $\mathrm{V}$ doped, and $\mathrm{Nb}-\mathrm{V}$ co-doped (111) TaON nanosheets. Appl. Surf. Sci. 2021, 541, 148572. [CrossRef]

100. Shao, Y.; Feng, K.; Guo, J.; Zhang, R.; He, S.; Wei, X.; Lin, Y.; Ye, Z.; Chen, K. Electronic structure and enhanced photoelectrocatalytic performance of $\mathrm{Ru}_{\mathrm{x}} \mathrm{Zn}_{1-\mathrm{x}} \mathrm{O} / \mathrm{Ti}$ electrodes. J. Adv. Ceram. 2021, 10, 1025-1041. [CrossRef]

101. Shen, J.; Li, F.; Wu, Y.; Fu, L.; Zhang, B. Preparation of doped $\mathrm{TiO}_{2}$ nanofiber membranes through electrospinning and their application for photocatalytic degradation of malachite green. J. Mater. Sci. 2014, 49, 2303-2314. [CrossRef]

102. Tsukamoto, D.; Shiraishi, Y.; Sugano, Y.; Ichikawa, S.; Tanaka, S. Gold Nanoparticles Located at the Interface of Anatase/Rutile $\mathrm{TiO}_{2}$ Particles as Active Plasmonic Photocatalysts for Aerobic Oxidation. J. Am. Chem. Soc. 2012, 134, 6309-6315. [CrossRef]

103. Jain, P.K.; Huang, X.; El-Sayed, I.H.; El-Sayed, M.A. Noble metals on the nanoscale: Optical and photothermal properties and some applications in imaging, sensing, biology, and medicine. Cheminform 2010, 40, 1578-1586.

104. Wang, C.; Astruc, D. Nanogold plasmonic photocatalysis for organic synthesis and clean energy conversion. Chem. Soc. Rev. 2014, 43, 7188-7216. [CrossRef] [PubMed]

105. Fan, Q.; Chen, X.; Wei, L.; Yang, K.; Yu, C. The role of photoluminescence induced by $\mathrm{Yb}^{3+} / \mathrm{Yb}^{2+}$ transformation in promoting the $\mathrm{SPR}$ effect in $\mathrm{Pd} / \mathrm{Yb}^{\mathrm{n}+} / \mathrm{BiOBr}$ photocatalyst system. Opt. Mater. 2020, 109, 110316. [CrossRef] 
106. Gao, H.; Zhang, P.; Zhao, J.; Zhang, Y.; Hu, J.; Shao, G. Plasmon enhancement on photocatalytic hydrogen production over the Z-scheme photosynthetic heterojunction system. Appl. Catal. B Environ. 2017, 210, 297-305. [CrossRef]

107. Zhuo, S.; Shao, M.; Lee, S.T. Upconversion and Downconversion Fluorescent Graphene Quantum Dots: Ultrasonic Preparation and Photocatalysis. ACS Nano 2012, 6, 1059-1064. [CrossRef] [PubMed]

108. Wang, H.Q.; Batentschuk, M.; Osvet, A.; Pinna, L.; Brabec, C.J. Rare-Earth Ion Doped Up-Conversion Materials for Photovoltaic Applications. Adv. Mater. 2011, 23, 2675-2680. [CrossRef]

109. Gao, W.; Wu, Y.; Lu, G. $980 \mathrm{~nm}$ NIR light driven overall water splitting over a combined CdS-RGO-NaYF4-Yb $\mathrm{B}^{3+} / \mathrm{Er}^{3+} \mathrm{photocata-}^{-}$ lyst. Catal. Sci. Technol. 2020, 10, 2389-2397. [CrossRef]

110. Mao, Z.; Xie, R.; Fu, D.; Zhang, L.; Xu, H.; Zhong, Y.; Sui, X. PAN supported Ag-AgBr@Bi ${ }_{20} \mathrm{TiO}_{32}$ electrospun fiber mats with efficient visible light photocatalytic activity and antibacterial capability. Sep. Purif. Technol. 2017, 176, 277-286. [CrossRef]

111. Chang, W.; Xu, F.; Mu, X.; Ji, L.; Ma, G.; Nie, J. Fabrication of nanostructured hollow $\mathrm{TiO}_{2}$ nanofibers with enhanced photocatalytic activity by coaxial electrospinning. Mater. Res. Bull. 2013, 48, 2661-2668. [CrossRef]

112. Khore, S.K.; Kadam, S.R.; Kale, B.B.; Sonawane, R.S. A green approach: Scalable dry media synthesis of a $\gamma$-TaON photocatalyst for solar H2 production and rhodamine B degradation. Catal. Sci. Technol. 2020, 4, 4671-4678. [CrossRef]

113. Kim, J.Y.; Lee, M.H.; Kim, J.; Kim, C.W.; Youn, D.H. Facile nanocrystalline $\mathrm{Ta}_{3} \mathrm{~N}_{5}$ synthesis for photocatalytic dye degradation under visible light. Chem. Phys. Lett. 2020, 738, 136900. [CrossRef]

114. Raza, A.; Shen, H.; Haidry, A.A. Novel $\mathrm{Cu}_{2} \mathrm{ZnSnS}_{4} / \mathrm{Pt} / \mathrm{g}-\mathrm{C}_{3} \mathrm{~N}_{4}$ heterojunction photocatalyst with straddling band configuration for enhanced solar to fuel conversion. Appl. Catal. B Environ. 2020, 277, 119239. [CrossRef]

115. Xu, J.; Sun, X.; Shan, Y.; Xu, J.; Wang, G.; Wang, L. Enhanced UV-light driven photocatalytic performances and recycling properties of $\mathrm{TiO}_{2} / \mathrm{AlON}$ composite photocatalyst. Ceram. Int. 2019, 45, 6767-6773. [CrossRef]

116. Zhang, S.; Zhang, Z.; Li, B.; Dai, W.; Si, Y.; Yang, L.; Luo, S. Hierarchical $\mathrm{Ag}_{3} \mathrm{PO}_{4} @ Z \mathrm{ZnI}_{2} \mathrm{~S}_{4}$ nanoscoparium: An innovative Z-scheme photocatalyst for highly efficient and predictable tetracycline degradation. J. Colloid Interface Sci. 2020, 586, 708-718. [CrossRef]

117. Hua, H.; Feng, F.; Du, M.; Ma, Y.; Pu, Y.; Zhang, J.; Li, X.A. 0D-2D Z-Scheme photocatalyst Cd $\mathrm{C}_{0.5} \mathrm{Zn}_{0.5} \mathrm{~S}_{\mathrm{B}} \mathrm{Bi}_{2} \mathrm{Fe}_{4} \mathrm{O}_{9}$ for effective hydrogen evolution from water. Appl. Surf. Sci. 2021, 541, 148428. [CrossRef]

118. Jiang, L.; Li, J.; Li, Y.; Wu, X.; Zhang, G. Promoted charge separation from nickel intervening in $\left[\mathrm{Bi}_{2} \mathrm{O}_{2}\right]^{2+}$ layers of $\mathrm{Bi}_{2} \mathrm{O}_{2} \mathrm{~S}$ crystals for enhanced photocatalytic $\mathrm{CO}_{2}$ conversion. Appl. Catal. B Environ. 2021, 294, 120249. [CrossRef]

119. Xiang, H.; Xing, Y.; Dai, F.; Wang, H.; Su, L.; Miao, L.; Zhang, G.; Wang, Y.; Qi, X.; Yao, L.; et al. High-entropy ceramics: Present status, challenges, and a look forward. J. Adv. Ceram. 2021, 10, 385-441. [CrossRef]

120. Li, T.; Yao, Y.; Ko, B.H.; Huang, Z.; Dong, Q.; Gao, J.; Chen, W.; Li, J.; Li, S.; Wang, X.; et al. Carbon-Supported High-Entropy Oxide Nanoparticles as Stable Electrocatalysts for Oxygen Reduction Reactions. Adv. Funct. Mater. 2021, 31, 2010561. [CrossRef]

121. Wang, H.; Zhang, L.; Chen, Z.; Hu, J.; Li, S.; Wang, Z.; Liu, J.; Wang, X. Semiconductor heterojunction photocatalysts: Design, construction, and photocatalytic performances. Chem. Soc. Rev. 2014, 43, 5234-5244. [CrossRef]

122. Rhoderick, E.H. Metal-semiconductor contacts. IEEE Proc. 1982, 129, 1-14. [CrossRef]

123. Zhang, S.; Zhang, B.P.; Li, S.; Huang, Z.; Yang, C.; Wang, H. Enhanced photocatalytic activity in Ag-nanoparticle-dispersed $\mathrm{BaTiO}_{3}$ composite thin films: Role of charge transfer. J. Adv. Ceram. 2017, 6, 1-10. [CrossRef]

124. Li, H.; Bian, Z.; Zhu, J.; Huo, Y.; Lu, Y. Mesoporous Au/ $\mathrm{TiO}_{2}$ Nanocomposites with Enhanced Photocatalytic Activity. J. Am. Chem. Soc. 2007, 129, 4538-4539. [CrossRef] [PubMed]

125. Yang, L.A.; Dan, L.A.; Tl, A.; Wei, Z.A.; Xw, A.; Xh, B.; Hya, C. Plasmonic Z-scheme Pt-Au/BiVO 4 photocatalyst: Synergistic effect of crystal-facet engineering and selective loading of Pt-Au cocatalyst for improved photocatalytic performance. J. Colloid Interface Sci. 2020, 570, 232-241.

126. Luo, J.; Li, R.; Chen, Y.; Zhou, X.; Ning, X.; Zhan, L.; Ma, L.; Xu, X.; Xu, L.; Zhang, L. Rational design of Z-scheme LaFeO $3 /$ SnS $_{2}$ hybrid with boosted visible light photocatalytic activity towards tetracycline degradation. Sep. Purif. Technol. 2019, 210, 417-430. [CrossRef]

127. Xia, P.; Zhu, B.; Cheng, B.; Yu, J.; Xu, J. 2D/2D g- $\mathrm{C}_{3} \mathrm{~N}_{4} / \mathrm{MnO}_{2}$ Nanocomposite as a Direct Z-Scheme Photocatalyst for Enhanced Photocatalytic Activity. ACS Sustain. Chem. Eng. 2017, 6, 965-973. [CrossRef]

128. Wang, S.; Zhu, B.; Liu, M.; Zhang, L.; Yu, J.; Zhou, M. Direct Z-scheme ZnO/CdS hierarchical photocatalyst for enhanced photocatalytic $\mathrm{H}_{2}$-production activity. Appl. Catal. B Environ. 2019, 243, 19-26. [CrossRef]

129. Ming, K.; Li, Y.; Chen, X.; Tian, T.; Zhao, X. Tuning the relative concentration ratio of bulk defects to surface defects in TiO 2 nanocrystals leads to high photocatalytic efficiency. J. Am. Chem. Soc. 2011, 133, 16414.

130. Jiang, L.; Yang, J.; Yuan, X.; Guo, J.; Liang, J.; Tang, W.; Chen, Y.; Li, X.; Wang, H.; Chu, W. Defect engineering in polymeric carbon nitride photocatalyst: Synthesis, properties and characterizations. Adv. Colloid Interface Sci. 2021, 296, 102523. [CrossRef] [PubMed]

131. Liang, X.; Wang, P.; Gao, Y.; Huang, H.; Tong, F.; Zhang, Q.; Wang, Z.; Liu, Y.; Zheng, Z.; Dai, Y.; et al. Design and synthesis of porous $\mathrm{M}-\mathrm{ZnO} / \mathrm{CeO}_{2}$ microspheres as efficient plasmonic photocatalysts for nonpolar gaseous molecules oxidation: Insight into the role of oxygen vacancy defects and $\mathrm{M}=\mathrm{Ag}$, Au nanoparticles. Appl. Catal. B Environ. 2020, 260, 118151. [CrossRef] 